\title{
Lemur Diversity in Madagascar
}

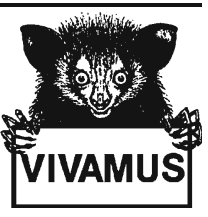

\author{
Russell A. Mittermeier • Jörg U. Ganzhorn • \\ William R. Konstant • Kenneth Glander • \\ Ian Tattersall • Colin P. Groves • \\ Anthony B. Rylands • Andreas Hapke • \\ Jonah Ratsimbazafy • Mireya I. Mayor • \\ Edward E. Louis Jr. • Yves Rumpler • \\ Christoph Schwitzer • Rodin M. Rasoloarison
}

Received: 1 February 2007 / Accepted: 3 June 2008 /

Published online: 4 December 2008

(C) Springer Science + Business Media, LLC 2008

\begin{abstract}
A basic understanding of the taxonomy, diversity, and distributions of primates is essential for their conservation. This review of the status of the taxonomy of lemurs is based on a 5-d workshop entitled "Primate Taxonomy for the New Millennium," held at the Disney Institute, Orlando, Florida, in February 2000. The aim is not to present a taxonomic revision, but to review our current understanding of the diversity and current and past ranges of lemurs and indicate where there is controversy, discrepancy, or lack of knowledge. Our goal therefore is to provide a baseline for future taxonomic investigation, as well as a clearer focus for research
\end{abstract}

\section{R. A. Mittermeier}

Conservation International, Arlington, VA 22202, USA

e-mail: r.mittermeier@conservation.org

\section{J. U. Ganzhorn • A. Hapke}

Department of Animal Ecology and Conservation, Hamburg University, 20146 Hamburg, Germany

\section{W. R. Konstant}

Houston Zoological Gardens, Houston, TX 77030, USA

K. Glander

Biological Anthropology and Anatomy Department, Duke University, Durham, NC 27705, USA

I. Tattersall

Department of Anthropology, American Museum of Natural History, New York, NY 10024, USA

C. P. Groves

Archaeology and Anthropology, Faculty of Arts, The Australian National University, Canberra, ACT 0200, Australia

A. B. Rylands $(\square)$

Center for Applied Biodiversity Science, Conservation International, Arlington, VA 22202, USA

e-mail: a.rylands@conservation.org 
and conservation priorities. We here focus on the lemurs of Madagascar and recognize 5 families, 15 genera, and 99 species and subspecies. We list 39 species of lemurs described since 2000: 2 dwarf lemurs, Cheirogaleus; 11 mouse lemurs, Microcebus; a giant mouse lemur, Mirza; a bamboo lemur, Hapalemur; 17 sportive lemurs, Lepilemur; and 7 woolly lemurs, Avahi. Taxonomic revisions have resulted in the resurrection of a further 9 taxa. However, the figures do not represent the total diversity of Malagasy lemurs because more new species are being identified via new field studies and accompanying genetic research, and should be described in the near future.

Keywords diversity $\cdot$ lemurs $\cdot$ Madagascar $\cdot$ taxonomy

\title{
Introduction
}

This paper is the last in a series of 4 that resulted from a 5-d workshop entitled "Primate Taxonomy for the New Millennium," held at the Disney Institute, Orlando, Florida, February 25-29, 2000, and organized by the IUCN/SSC Primate Specialist Group (PSG), The Center for Environmental Research and Conservation (CERC) at Columbia University, Conservation International, and the Margot Marsh Biodiversity Foundation. The rationale behind the workshop was the need for a basic understanding of the diversity, taxonomy, and distribution of all primates as a fundamental basis for efforts to conserve them and to maintain the full diversity of the order. Although much research has been conducted on primate taxonomy over the past 5 decades, the taxonomy of many different groups remains unclear, including that of species at greatest risk of extinction. This confounds conservation

\author{
A. Hapke \\ Institut für Anthropologie, Johannes-Gutenberg-Universität Mainz, 55099 Mainz, Germany \\ J. Ratsimbazafy \\ Durrell Wildlife Conservation Trust - Madagascar, 101 Antananarivo, Madagascar
}

M. I. Mayor

Department of Anthropology, State University of New York, Stony Brook, NY 11794, USA

M. I. Mayor

National Geographic, Washington, DC 20036, USA

E. E. Louis Jr.

Center for Conservation and Research, Henry Doorly Zoo, Omaha, NE 68107, USA

Y. Rumpler

Faculté de Médecine, Institut d'Embryologie, Université Louis Pasteur, EA3428 Strasbourg, France

C. Schwitzer

Bristol Zoo Gardens, Clifton, Bristol BS8 3HA, England

R. M. Rasoloarison

Département de Biologie Animale, Faculté des Sciences, Université d'Antananarivo,

Antananarivo 101, Madagascar 
efforts and makes it difficult to determine how resources should best be allocated. The Orlando meeting involved 25 experts in various aspects of primate taxonomy. The main objectives were to draw up a list of recognized primate taxa to serve as the basis for future conservation action and to take advantage of the presence of so many experts to begin an assessment of the conservation status of all primates for the IUCN Red List. The results of the assessment for the Neotropical primates were published in 2000 (Rylands et al. 2000), and will be revisited in a further publication (Rylands and Mittermeier, in press). Grubb et al. (2003) published conclusions regarding the African primates, and Brandon-Jones et al. (2004) published the agreed listing of the Asian primates. However, all of them are to be regarded as provisional. Here we report on our findings and conclusions for the lemurs of Madagascar, along with the numerous taxa that researchers have described since 2000.

Morphological and (especially) cytogenetic and molecular genetic studies are resulting in some major changes in our understanding of the diversity, phylogeny, and systematics of the lemurs (Fausser et al. 2002; Mayor et al. 2004; Ravoarimanana 2001; Rumpler 2000, 2004), as well as the identification of numerous new species (Andriaholinirina et al. 2006a; Andriantompohavana et al. 2006, 2007; Craul et al. 2007; Kappeler et al. 2005; Lei et al. 2008; Louis et al. 2006a, b; Olivieri et al. 2007; Rabarivola et al. 2006; Radespiel et al. 2008; Rasoloarison et al. 2000; Rylands et al. 2002; Thalmann and Geissmann 2000, 2005; Zaramody et al. 2006; Zimmermann et al. 1998). Groves and Tattersall (1991), Groves (2000, 2001, 2005, 2007), and Groves and Helgen (2007) revised existing museum material intensively. As a result of the aforementioned work, primatologists described 39 new species from the time of the Orlando workshop in 2000 to September 2008 and resurrected 9 other taxa, bringing the total number of taxa recognized here to 99 ( 97 species).

It is not our aim to present another taxonomic revision, but instead to review the current situation and to indicate controversy, discrepancies, and gaps in our understanding of the diversity of the Madagascar lemurs and their current and past ranges. We hope that this will provide a baseline for future taxonomic investigation and a clearer focus for conservation priorities. Our resulting taxonomic list is in Table I, together with the earlier taxonomic arrangements of Mittermeier et al. (1994), Goodman et al. (2003), and Groves (2005). As is inevitable in producing a list of this kind, there are, in many cases, disparate opinions and standpoints of the authors themselves regarding the affinities and validity or otherwise of certain named forms and the appropriate taxonomic ranking (species or subspecies). The 14 authors involved in constructing the list, the first 6 of whom comprised the core working group at the 2000 primate taxonomy workshop, do not necessarily agree on the arrangements for all of the genera and should not be taken to task if they express alternative opinions and standpoints elsewhere. The list results from the majority opinion and we hope we have indicated adequately where doubts and controversies exist. Groves (2001, 2004) and Tattersall (2007) discussed many of the issues involved in the taxonomic classification of the primates, and the latter author presented contrasting viewpoints for the lemurs in particular.

Before providing details on the different lemur taxa, we summarize some of the concepts that have contributed to uncertainties in lemur taxonomy. They relate mainly to the multiple interpretations of what constitutes a species. Scientists, 
Table I Lemur taxa recognized in this paper in comparison to Mittermeier et al. (1994), Groves' taxonomy (Groves 2005), and the "pre-Groves system" extended by new taxa and summarized by Goodman et al. (2003)

\begin{tabular}{|c|c|c|c|}
\hline $\begin{array}{l}\text { Mittermeier et al. } \\
\text { (1994) }\end{array}$ & Goodman et al. (2003) & Groves (2005) & $\begin{array}{l}\text { Lemur taxa recognized in the } \\
\text { present paper }\end{array}$ \\
\hline $\begin{array}{l}\text { Family Cheirogaleidae } \\
\text { Microcebus murinus } \\
\text { M. rufus } \\
\text { M. myoxinus }\end{array}$ & $\begin{array}{l}\text { Family Cheirogaleidae } \\
\text { Microcebus murinus } \\
\text { M. rufus } \\
\text { M. myoxinus } \\
\text { M. griseorufus } \\
\text { M. ravelobensis } \\
\text { M. berthae } \\
\text { M. sambiranensis } \\
\text { M. tavaratra }\end{array}$ & $\begin{array}{l}\text { Family Cheirogaleidae } \\
\text { Microcebus murinus } \\
\text { M. rufus } \\
\text { M. myoxinus } \\
\text { M. griseorufus } \\
\text { M. ravelobensis } \\
\text { M. berthae } \\
\text { M. sambiranensis } \\
\text { M. tavaratra }\end{array}$ & $\begin{array}{l}\text { Family Cheirogaleidae } \\
\text { 1. Microcebus murinus } \\
\text { 2. M. rufus } \\
\text { 3. M. myoxinus } \\
\text { 4. M. griseorufus } \\
\text { 5. M. ravelobensis } \\
\text { 6. M. berthae } \\
\text { 7. M. sambiranensis } \\
\text { 8. M. tavaratra } \\
\text { 9. M. lehilahytsara } \\
\text { 10. M. jollyae } \\
\text { 11. M. mittermeieri } \\
\text { 12. M. simmonsi } \\
\text { 13. M. mamiratra } \\
\text { 14. M. danfossi } \\
\text { 15. M. bongolavensis } \\
\text { 16. M. macarthurii }\end{array}$ \\
\hline Mirza coquereli & Mirza coquereli & Mirza coquereli & $\begin{array}{l}\text { 17. Mirza coquereli } \\
\text { 18. Mirza zaza }\end{array}$ \\
\hline Allocebus trichotis & Allocebus trichotis & Allocebus trichotis & 19. Allocebus trichotis \\
\hline Cheirogaleus medius & $\begin{array}{l}\text { Cheirogaleus medius } \\
\text { C. adipicaudatus }\end{array}$ & $\begin{array}{l}\text { Cheirogaleus medius } \\
\text { C. adipicaudatus }\end{array}$ & $\begin{array}{l}\text { 20. Cheirogaleus medius } \\
\text { 21. C. adipicaudatus }\end{array}$ \\
\hline C. major & $\begin{array}{l}\text { C. major } \\
\text { C. } \text { crossleyi } \\
\text { C. sibreei } \\
\text { C. ravus } \\
\text { C. minusculus }\end{array}$ & $\begin{array}{l}\text { C. major } \\
\text { C. } \text { crossleyi } \\
\text { C. sibreei } \\
\text { C. ravus } \\
\text { C. minusculus }\end{array}$ & $\begin{array}{l}\text { 22. C. major } \\
\text { 23. C. crossleyi } \\
\text { 24. C. sibreei } \\
\text { 25. C. ravus } \\
\text { 26. C. minusculus }\end{array}$ \\
\hline $\begin{array}{l}\text { Phaner furcifer } \\
\text { furcifer }\end{array}$ & Phaner furcifer & Phaner furcifer & 27. Phaner furcifer \\
\hline P. furcifer pallescens & P. pallescens & P. pallescens & 28. P. pallescens \\
\hline P. furcifer parienti & P. parienti & P. parienti & 29. P. parienti \\
\hline $\begin{array}{l}\text { P. furcifer } \\
\text { electromontis }\end{array}$ & P. electromontis & P. electromontis & 30. P. electromontis \\
\hline Family Lemuridae & Family Lemuridae & Family Lemuridae & Family Lemuridae \\
\hline Lemur catta & Lemur catta & Lemur catta & 31. Lemur catta \\
\hline Eulemur fulvus fulvus & Eulemur fulvus fulvus & Eulemur fulvus & 32. Eulemur fulvus \\
\hline E. fulvus sanfordi & E. fulvus sanfordi & E. sanfordi & 33. E. sanfordi \\
\hline E. fulvus albifrons & E. fulvus albifrons & E. albifrons & 34. E. albifrons \\
\hline E. fulvus rufus & E. fulvus rufus & E. rufus & $\begin{array}{l}\text { 35. E. rufus } \\
\text { 36. E. rufifrons }\end{array}$ \\
\hline & & E. cinereiceps & \\
\hline E. fulvus collaris & E. fulvus collaris & E. collaris & 37. E. collaris \\
\hline E. fulvus albocollaris & E. fulvus albocollaris & E. albocollaris & 38. E. cinereiceps \\
\hline E. macaco macaco & E. macaco macaco & E. macaco macaco & 39. E. macaco \\
\hline E. macaco flavifrons & E. macaco flavifrons & E. macaco flavifrons & 40. E. flavifrons \\
\hline E. coronatus & E. coronatus & E. coronatus & 41. E. coronatus \\
\hline E. rubriventer & E. rubriventer & E. rubriventer & 42. E. rubriventer \\
\hline E. mongoz & E. mongoz & E. mongoz & 43. E. mongoz \\
\hline $\begin{array}{l}\text { Hapalemus griseus } \\
\text { griseus }\end{array}$ & $\begin{array}{l}\text { Hapalemus griseus } \\
\text { griseus }\end{array}$ & $\begin{array}{l}\text { Hapalemus griseus } \\
\text { griseus }\end{array}$ & 44. Hapalemur griseus \\
\hline & H. g. meridionalis & H. g. meridionalis & $\begin{array}{l}\text { 45. H. meridionalis } \\
\text { 46. H. gilberti }\end{array}$ \\
\hline H. griseus alaotrensis & H. griseus alaotrensis & H. alaotrensis & 47. H. alaotrensis \\
\hline H. aureus & H. aureus & H. aureus & 48. H. aureus \\
\hline H. griseus occidentalis & H. occidentalis & H. occidentalis & 49. H. occidentalis \\
\hline
\end{tabular}




Hapalemur simus
Varecia variegata
variegata

V. v. rubra
Family Megaladapidae
Lepilemur mustelinus
L. microdon
L. leucopus
L. ruficaudatus
L. edwardsi
L. dorsalis
L. septentrionalis

Family Indriidae

Indri indri

Avahi laniger

A. occidentalis

\section{Hapalemur simus \\ Varecia variegata variegata}

V. v. rubra

Family Lepilemuridae

Lepilemur mustelinus

L. microdon

L. leucopus

L. ruficaudatus

L. edwardsi

L. dorsalis

L. septentrionalis

L. ankaranensis

Family Indriidae

Indri indri

Avahi laniger

A. occidentalis

A. unicolor
Prolemur simus

Varecia variegata

variegata

V. v. editorum

V. v. subcincta

V. rubra

Family Lepilemuridae

Lepilemur mustelinus

L. microdon

L. leucopus

L. ruficaudatus

L. edwardsi

L. dorsalis

L. septentrionalis

L. ankaranensis
Family Indriidae

Indri indri indri

I. i. variegatus

Avahi laniger

A. occidentalis

A. unicolor

Propithecus diadema
diadema
$P . d$. candidus
$P . d$. edwardsi
P. d. perrieri
$P . v$. verrreauxi
$P . v$. deckenii
$P . v$. coronatus
P. v. coquereli
P. tattersalli
Family Daubentoniidae
Daubentonia
madagascariensis

Propithecus diadema
diadema
$P . d$. candidus
P. d. edwardsi
P. d. perrieri
$P$. v. verrreauxi
$P$. v. deckenii
$P$. v. coronatus
$P$. v. coquereli
P. tattersalli
Family Daubentoniidae
Daubentonia
madagascariensis

Propithecus diadema diadema

P. d. candidus

P. edwardsi

P. perrieri

$P$. verreauxi

P. deckenii deckenii

P. deckenii coronatus

P. coquereli

P. tattersalli

Family Daubentoniidae

Daubentonia

madagascariensis
50. Prolemur simus

51. Varecia variegata variegata

52. V. v. editorum

53. V. v. subcincta

54. V. rubra

Family Lepilemuridae

55. Lepilemur mustelinus

56. L. microdon

57. L. leucopus

58. L. ruficaudatus

59. L. edwardsi

60. L. dorsalis

61. L. septentrionalis

62. L. ankaranensis

63. L. aeeclis

64. L. randrianasoli

65. L. sahamalazensis

66. L. mittermeieri

67. L. ahmansoni

68. L. betsileo

69. L. fleuretae

70. L. grewcocki

71. L. hubbardi

72. L. jamesi

73. L. milanoii

74. L. petteri

75. L. seali

76. L. tymerlachsoni

77. L. wrighti

78. L. otto

79. L. scottorum

Family Indriidae

80. Indri indri

81. Avahi laniger

82. A. occidentalis

83. A. unicolor

84. A. cleesei

85. A. peyrierasi

86. A. meridionalis

87. A. ramanantsoavani

88. A. betsileo

89. A. mooreorum

90. Propithecus

diadema

91. P. candidus

92. P. edwardsi

93. . perrieri

94. $P$. verreauxi

95. P. deckenii

96. P. coronatus

97. P. coquereli

98. P. tattersalli

Family Daubentoniidae

99. Daubentonia

madagascariensis

In all, we recognize 5 families, 15 genera, and 99 species and subspecies. 
politicians, and the public are familiar with the term species, and most arguments concerning biological diversity use the term. Yet there are many different definitions, as indicated by Groves $(2001,2004)$. Hey (2001) provided a review, listing no less than 24 different species concepts. Hey (2001, p. 328) argued that the diversity of definitions results from 2 processes: 1) the evolutionary processes that have caused biological diversity and 2) the human mental apparatus that recognizes and gives names to patterns of recurrence.

The search for a definition of the species is essentially the search for a way to operationalize the Evolutionary Species ["a lineage... evolving separately from others and with its own unitary evolutionary role and tendencies" (Simpson 1961, pp. 153-154)].

Four concepts are most often applied in defining taxonomic units: 1) The Biological Species Concept, which is "groups of actually or potentially interbreeding natural populations which are reproductively isolated from other such groups" (Mayr 1963, p. 19); 2) The Phylogenetic Species Concept, which is "the smallest diagnosable cluster of individual organisms within which there is a parental pattern of ancestry and descent" (Cracraft 1983, p. 170); 3) The Recognition Species Concept, which is "that most inclusive population of biparental organisms which share a common fertilisation system" (Paterson 1986, p. 63); and 4) Subspecies, which, according to Mayr (1963) and Mayr and Ashlock (1991), are "an aggregation of phenotypically similar populations of a species that inhabit a geographical segment of the distribution range of a species and can be taxonomically distinguished from other populations of that species" (Thalmann et al. 2002, p. 12). To be considered a subspecies, $c a$. $75 \%$ of the individuals of a population should be different from all other individuals of the species. Thalmann et al. (2002) applied the criterion to resolve the debate as to whether Propithecus verreauxi deckenii and $P$. v. coronatus should be considered distinct subspecies or whether they should more correctly be lumped into one taxonomic unit.

In addition to the formal concepts, there is a widespread assumption, rarely made fully explicit, that species ought to be defined by certain degrees of difference. The expectation lies behind some of the taxonomic conclusions in molecular investigations: the amount of difference, e.g., in a mitochondrial DNA (mtDNA) sequence, should be so much percent for 2 taxa to rank as species. It was only in 2001 that researchers gave the concept a name: the Genetic Species Concept (Bradley and Baker 2001); the authors showed that there is indeed a particular degree of genetic distance that characterizes subspecies, sister species, and so on, but it is by no means universal and one cannot use it as a strict taxonomic criterion. The same authors have more recently defined a Genetic Species as "a group of genetically compatible interbreeding natural populations that is genetically isolated from other such groups" (Baker and Bradley 2006, p. 645), and they reiterate that, though based on the idea that "speciation is the accumulation of genetic changes in 2 lineages... that produced genetic isolation and protection of the integrity of the 2 respective gene pools that have independent evolutionary fates" (ibid.), there is no certainty about genetic distances between species, and in effect Genetic Species are virtually identical to Phylogenetic Species. This underlines yet again that species difference is a quality, not a quantity. 
The so-called Distinct Population Segment, which is listed under the U.S. Endangered Species Act, is another unit relevant for conservation. The term was introduced in 1978 to protect populations of charismatic species such as timber wolves and grizzly bears that are rare locally but can be abundant elsewhere (Clark 2002; DeWeerdt 2002). Distinct population segments as such are not equivalent to subspecies, which are populations that "inhabit a geographical segment."

Debate continues as to which of the taxonomic concepts should be the basis for conservation, with some preferring the Phylogenetic Species Concept and others the Biological Species Concept. Part of the discussion revolved around some still unresolved questions, two of which are outlined below.

\section{Discrepancies Between Traits}

Taxonomy, systematics, and phylogenetic reconstructions are based on morphological, cytological, and genetic traits. It has been a matter of debate as to how diverging results based on the different traits can be reconciled. Researchers currently consider integration of the different aspects based on objective criteria problematic because morphological traits that result from several interacting coding genes are compared with sequences of noncoding DNA, coding DNA, and chromosomal rearrangements of unknown consequences. Several reviewers have analyzed problems arising from combining gene trees and species trees (Nichols 2001) and from linking speciation to chromosomal rearrangements (Rieseberg 2001), and also concerning the kinds of genetic differences that distinguish species (Orr 2001). The problem is that there is often little or no correlation between genetic distinctiveness and speciation or morphological shift. Further, some difficulties exist because nature and our own, often biased, expectations do not match. Yoder (1997), Thalmann (2003), Rumpler (2004), and Ganzhorn et al. (2006) summarized some of the discrepancies as they occur in lemurs. In the main, we take the view that any apparently heritable character variation is appropriate in taxonomy.

\section{Natural Hybridization}

Several researchers who have demonstrated hybridization between morphologically clearly distinct units have questioned the application of the Biological Species Concept for lemurs. Hybrids have been reported for Eulemur mongoz $\times$ Eulemur $(f$.) fulvus (Zaramody and Pastorini 2001), Eulemur (m.) macaco $\times$ E. (f.) fulvus at Manongarivo (Goodman and Schütz 2000), E. (m.) macaco $\times$ E. (m.) flavifrons (Meyers et al. 1989; Rabarivola et al. 1991), and E. (f.) fulvus $\times$ E. (f.) rufus (Lehman and Wright 2000). Johnson and Wyner (2000), Johnson (2002), and Wyner et al. (2002) also reported a zone of hybridization between Eulemur (fulvus) albocollaris (now called E. cinereiceps) and E. (f.) rufus.

The examples illustrate the difficulties in the classification of biological diversity. However, classifications are conventions and thus tools to be used for specific purposes. A full understanding of the diversity of extant lemurs is vital if we are to conserve them and, though there is doubt in any assessment, we lean toward maintaining controversial taxa and species level classifications, as discussed by Groves (2001, 2004). 
The taxonomic arrangement that we recommend in Table I and describe below is our majority opinion on the current state of lemur taxonomy, and captures, to the best extent possible on the basis of available knowledge, the distinct units that we consider essential for the development of an effective strategy for the conservation of the full range of lemur diversity. Further, several of the authors consider the subspecies concept largely useless for classifying the primates of Madagascar, with perhaps a few exceptions. We recognize a total of 5 families, 15 genera, and 99 species and subspecies (Table I).

\section{The Lemurs of Madagascar}

The living primates of Madagascar comprise 5 families: Cheirogaleidae, Lemuridae, Lepilemuridae, Indriidae, and Daubentoniidae. This is an extraordinary level of higher order diversity for an island of only $581,540 \mathrm{~km}^{2}$. The same number of nonhuman primate families occurs in the Neotropics (Callitrichidae, Cebidae, Aotidae, Pitheciidae, Atelidae) and in the entire Asian region (Tarsiidae, Lorisidae, Cercopithecidae, Hylobatidae, Hominidae), and is 1 more than the number of families native to mainland Africa (Lorisidae, Galagidae, Cercopithecidae, Hominidae). This is especially impressive in light of the fact that Madagascar is $<2-3 \%$ the size of each of the other major continental regions. Further, and of particular concern for conservation purposes, $<10 \%$ of Madagascar remains sufficiently intact to serve as habitat for wild lemur populations, meaning that all of the country's primate diversity is confined to an area of $c a$. $50-60,000 \mathrm{~km}^{2}$.

We review by family and genus the taxonomy of all Madagascar's primates, with a discussion of the species and subspecies recognized, interpret the available information, and discuss the taxonomic questions as yet unresolved.

\section{Family Cheirogaleidae Gray, 1873}

Cheirogaleidae Gray, 1873 includes 5 genera: Microcebus, Mirza, Allocebus, Cheirogaleus, and Phaner. Cheirogaleid lemurs range in size from the world's smallest primate at $c a .30 \mathrm{~g}$ to $c a .600 \mathrm{~g}$. All move quadrupedally, and most have elongated bodies and short legs. They sleep during the day in small nests of dead leaves or in holes in trees, and some undergo prolonged periods of seasonal torpor.

\section{Microcebus É. Geoffroy, 1828: Mouse lemurs}

Microcebus murinus (J. F. Miller, 1777): Gray mouse lemur

Microcebus rufus É. Geoffroy, 1834: Brown mouse lemur

Microcebus myoxinus Peters, 1852: Pygmy mouse lemur

Microcebus griseorufus Kollman, 1910: Rufous-gray mouse lemur

Microcebus ravelobensis Zimmermann et al., 1998: Lac Ravelobe or goldenbrown mouse lemur

Microcebus berthae Rasoloarison et al., 2000: Madame Berthe's mouse lemur Microcebus sambiranensis Rasoloarison et al., 2000: Sambirano mouse lemur Microcebus tavaratra Rasoloarison et al., 2000: Northern brown mouse lemur 
Microcebus lehilahytsara Roos and Kappeler in Kappeler et al., 2005: Goodman's mouse lemur

Microcebus mittermeieri Louis et al., 2006: Mittermeier's mouse lemur

Microcebus simmonsi Louis et al., 2006: Simmons' mouse lemur

Microcebus jollyae Louis et al., 2006: Jolly's mouse lemur

Microcebus mamiratra Andriantompohavana et al., 2006: Claire's mouse lemur

Microcebus danfossi Olivieri et al., 2007: Danfoss' mouse lemur

Microcebus bongolavensis Olivieri et al., 2007: Bongolava mouse lemur

Microcebus macarthurii Radespiel et al., 2008: MacArthur's mouse lemur

The current census of species in Microcebus indicates $\geq 16,12$ of which have been described within the last $10 \mathrm{yr}$. The mouse lemurs are the smallest of the Malagasy prosimians. They are nocturnal omnivores and one of the most abundant and widespread genera of lemurs.

Tattersall (1982) provided a detailed description of the entangled taxonomic history of Microcebus which, until recently, was believed to consist of only 2 species: Microcebus murinus, gray-colored and confined largely to dry forests of western Madagascar, and M. rufus, reddish and native to the country's more humid eastern forests. Petter (1962) and Petter et al. (1977) were the first to suggest that $\geq 2$ forms of reddish mouse lemur were readily distinguishable: an eastern one and what appeared to be distinct populations from the dry western forests of Ankarafantsika and Analabe. Atsalis et al. (1996) confirmed the distinction between the eastern and Analabe red mouse lemurs, as did Zimmermann et al. (1997, 1998) for the Ankarafantsika form, which they also found to be distinct.

For the western forms Rasoloarison et al. (2000) investigated specimens of Microcebus from 12 localities ranging from Ankarana in the north to Beza Mahafaly in the south and clarified some of the confusion of the assignments of names to the different types. Rasoloarison's own field surveys resulted in the description of 3 new species - Microcebus sambiranensis, M. tavaratra, and M. berthae- the resurrection of a fourth (M. griseorufus), and the redefinition of a fifth (M. myoxinus).

Primatologists once believed Microcebus murinus to range "throughout the forested areas of western, southern and southwestern Madagascar, from Fort Dauphin to the Sambirano region" (Mittermeier et al. 1994; Tattersall 1982, p. 119). Microcebus murinus occurs along the west coast from the humid evergreen littoral forests of Mandena in the southeast (east of Fort Dauphin/Tolagnaro; Ramanamanjato and Ganzhorn 2001) and north at least to Ankarafantsika in the northwest. Primatologists have assigned all individuals sighted or caught north of Ankarafantsika to Microcebus species other than M. murinus (cf. Randrianambinina et al. 2003). New evidence suggests that Microcebus cf. murinus is not monotypic but consists of several forms, which are distinct genetically and morphologically (Lahann et al. 2006; Pastorini et al. 2003).

Peters (1852) returned from a collecting expedition to Madagascar with 3 western mouse lemurs that he named Microcebus myoxinus and that Schwarz (1931) later declared to be a synonym of $M$. murinus. Based on the capture and measurement of $>80$ mouse lemurs, Schmid and Kappeler (1994) concluded that 2 species were present in the Kirindy/CFPF Forest northeast of Morondava: a larger, grayer Microcebus murinus and a smaller, more rufous species, for which they resurrected the name $M$. myoxinus. However, a renewed examination of the material that Peters 
(1852) collected indicated that the Kirindy/CFPF mouse lemurs represented another new species (later described as Microcebus berthae by Rasoloarison et al. 2000), and that M. myoxinus is actually the species that occurs in Aboalimena and Bemaraha, apparently from the north of the Tsiribihina River at least to the Soalala Peninsula (Rasoloarison et al. 2000).

Kollman (1910) described the subspecies Microcebus minor griseorufus from southern Madagascar, which Tattersall (1982) considered a synonym of M. murinus. Rasoloarison et al. (2000) elevated it to a full species, M. griseorufus. It is among the smallest of the mouse lemurs and occurs in southwestern Madagascar from the spiny forests in and around Berenty and Andohahela (Parcel 2; Yoder et al. 2002; Ganzhorn, unpubl. data), Lac Tsimanampetsotsa (Goodman et al. 2002; Louis et al. 2006a; Ralison 2006), and the Beza Mahafaly Special Reserve (Rasoazanabary 2004; Rasoloarison et al. 2000) north at least to Lamboharana, and northeast to Isalo (E. E. Louis, unpubl. data) and the Mikea forests north of Tuléar (Ganzhorn and Randriamanalina 2004).

On the basis of morphological measurements and comparison of vocalizations, Zimmermann et al. $(1997,1998)$ concluded that 2 species of mouse lemur inhabited the forest of Ampijoroa, within the Ankarafantsika Nature Reserve in northwestern Madagascar. In addition to the widespread Microcebus murinus, they described the new species $M$. ravelobensis, at present known only from the region of Ankarafantsika and suspected from the Reserve Spéciale de Bora (Randrianambinina et al. 2003).

Rasoloarison et al. (2000) described 3 new species of mouse lemur from western Madagascar, based largely on morphometric data that were subsequently supported by analyses of mtDNA (Yoder et al. 2000). Microcebus berthae, originally called $M$. myoxinus by Schmid and Kappeler (1994), was the name given to the diminutive brown mouse lemur from Kirindy/CFPF. Microcebus berthae is the world's smallest primate and has a restricted range, extending north from Kirindy/CFPF to Analabe, and south as far as the Andranomena Special Reserve (Schwab and Ganzhorn 2004).

Only slightly larger in size is Microcebus sambiranensis, another reddish-colored mouse lemur that occurs in the Manongarivo Special Reserve in northwestern Madagascar (Goodman and Soarimalala 2002) and possibly the forest of Mahilaka (Randrianambinina et al. 2003). Earlier reports had identified the Manongarivo mouse lemurs as Microcebus rufus (cf. Mittermeier et al. 1994; Nicoll and Langrand 1989; Tattersall 1982) or M. ruficeps (cf. Raxworthy and Rakotondraparany 1988).

The larger Microcebus tavaratra occurs in the Ankarana Special Reserve in far northern Madagascar. It is known only from Ankarana and Analamerana, to the east. It is not known whether Microcebus murinus is sympatric with M. tavaratra there. Andriantompohavana et al. (2006) conducted a molecular genetic analysis of 10 specimens from Mahamasina, Ankarana. As was the case for Microcebus sambiranensis, the Ankarana population was previously considered to be M. rufus (cf. Mittermeier et al. 1994; Nicoll and Langrand 1989).

Researchers assumed that Microcebus rufus occurs throughout Madagascar's humid eastern forests from Fort Dauphin in the south to Montagne d'Ambre in the north, including the Sambirano region (Tattersall 1982). However, the mouse lemurs are difficult to distinguish in the field at night, and researchers are reconsidering the current records of Microcebus rufus, based on visual field surveys. Petter et al. 
(1977) noted geographic variations in morphology, especially in ear size, throughout their range, and Groves (2001) suggested that northern specimens are darker and shorter-tailed than those from the south. The distinction of Microcebus cf. rufus into $\geq 2$ separate types, a northern and a southern form, seemed also justified based on genetic analyses (Pastorini et al. 2001b; Yoder et al. 2000). The form at the Sambirano, originally classified as Microcebus rufus, might actually be $M$. sambiranensis, one of the taxa described by Rasoloarison et al. (2000) because intensive surveys of the Réserve Spéciale de Manongarivo revealed that $M$. sambiranensis was the only form present (Goodman and Soarimalala 2002).

Roos and Kappeler in Kappeler et al. (2005) described a distinct form, Microcebus lehilahytsara, from Andasibe, in the province of Toamasina, diminutive even for mouse lemurs, being similar in head-body length to Microcebus berthae. Louis et al. (2006a) conducted a phylogenetic study of Microcebus via morphological and molecular genetic data: 555 base pairs (bp) of mtDNA D-loop sequence data. They identified an eastern clade with 7 forms, which they indicated were distinct species. They included Microcebus rufus, which they redefined, and 3 new species: M. mittermeieri in the north; the intermediate-sized M. jollyae in the southcentral eastern forests; and $M$. simmonsi from Betampona Special Reserve and Zahamena National Park in the north-central forests of the east coast.

Louis et al. (2006a) fixed the type locality of M. rufus as Ranomafana National Park (southeast of Fianarantsoa), and they indicated that its geographic range extended to the Mantadia National Park (Andasibe), but they noted that the mouse lemur from the Mantadia National Park, although similar in coloration and pelage patterns to M. rufus at Ranomafana, was smaller and genetically differentiated, and suggested it may be a different species (referred to as Microcebus sp. nova \#2). This seems likely to be Microcebus lehilahytsara described independently by Kappeler et al. (2005).

The northernmost species of the eastern clade was caught in Anjanaharibe-Sud Special Reserve, Province of Antsiranana. Microcebus mittermeieri is well differentiated genetically, and the smallest of the newly described Microcebus species from the eastern humid forest; at $40 \mathrm{~g}$, about $8 \mathrm{~g}$ smaller than $M$. lehilahytsara. It is lighter in color than typical Microcebus rufus. Microcebus simmonsi is a large species (78 g), orange-red, and occurs in the Zahamena National Park and Betampona Special Reserve, to the north of M. rufus and M. lehilahytsara. Lastly, Microcebus jollyae weighs ca. $60 \mathrm{~g}$ and occurs east and southeast of Ranomafana National Park; its distribution is currently believed to range from Kianjavato in the north to Manombo Special Reserve in the south. Louis et al. (2006a) identified 2 differentiated forms in the southern part of the range of Microcebus jollyae, and consider its distribution only temporary as more information becomes available. In the Makira region, Microcebus mittermeieri is sympatric with 2 other mouse lemurs, one of which Radespiel et al. (2008) described as Microcebus macarthurii, but the other remains undescribed owing to small sample size.

Louis et al. (2006a) also found that the mouse lemur from the island of Nosy Be in the northwest, west of the Manongarivo Special Reserve, was divergent from the mainland species there, Microcebus sambiranensis. They referred to it as Microcebus sp. nova \#4, and Andriantompohavana et al. (2006) subsequently described it as M. mamiratra, with the type locality Lokobe Special Reserve, Nosy Be, Province 
of Antsiranana. Andriantompohavana et al. (2006) found another mainland population from Antafondro, south of the Sambirano River in northwestern Madagascar, sp. nova \#5, to be closely related to Microcebus mamiratra but genetically distinct, and indicated that further research may result in its description as a separate taxon.

In a molecular genetic analysis of mouse lemur populations separated by rivers in northwestern Madagascar, Olivieri et al. (2007) described a further 3 species. Microcebus danfossi is from the reserves of Bora and Anjiamangirana, and $M$. bongolavensis is from the area around Port-Bergé and limited by the rivers Mahajamba and Sofia. The third species is Microcebus lokobensis, with the type locality "Province of Mahajanga, from the forest fragment near the village of Ampasimpohy $\left(13^{\circ} 23^{\prime} 24^{\prime \prime} \mathrm{S} ; 48^{\circ} 20^{\prime} 31^{\prime \prime} \mathrm{E}\right)$ which is the border of the Integrated Nature Reserve of Lokobe on the Island of Nosy Be" (Olivieri et al. 2007, p. 17). Andriantompohavana et al. (2006) also described a mouse lemur from the Island of Nosy Be (type locality "Province de Antsiranana, Nosy Be, Lokobe Special Reserve (ca. 132 $4^{\prime} 16.9^{\prime \prime} \mathrm{S} ; 048^{\circ} 18^{\prime} 11.2^{\prime} \mathrm{E}$ at 13 m.)." Both Olivieri et al. (2007) and Andriantompohavana et al. (2006) indicated that the species they described corresponded to Microcebus sp. nova \#4 of Louis et al. (2006a). Olivieri et al. (2007) noted that they sequenced loci different from the ones examined by Louis et al. (2006a), making comparison impossible. The diagnostic features given by both Louis et al. (2006a) and Olivieri et al. (2007) are genetic, except for morphometric measurements - ear length and width, lower leg length and toe length — which the latter authors used to compare Microcebus lokobensis with M. tavaratra from Ankarana and Analamerana to the north. Comparison of the authors' descriptions of the pelage of Microcebus lokobensis and M. mamiratra is not helpful in determining if they are the same or different. We consider Microcebus lokobensis to be a junior synonym of M. mamiratra.

By all accounts, there are numerous further species of Microcebus that have yet to be described, with populations having distinct genetic identities separated by even quite small rivers (E. E. Louis, unpubl. data).

\section{Allocebus Petter-Rousseaux and Petter, 1967: Hairy-eared dwarf lemur}

Allocebus trichotis (Günther, 1875): Hairy-eared mouse lemur, hairy-eared dwarf lemur Allocebus contains the single species A. trichotis, a tiny nocturnal dwarf lemur from the northern rain forests of eastern Madagascar that closely resembles mouse lemurs (Microcebus) in size and color, but from which it is easily distinguished by the wavy hair on its ears. Crossley collected the holotype in 1874, and Humblot another 2 specimens of Allocebus trichotis in 1880, but their origin is uncertain (Harcourt and Thornback 1990; Tattersall 1982). In 1965, A. Peyrieras captured individuals in the forest of Andranomahitsy, west of Mananara, but it was not until 1989 that Meier and Albignac $(1989,1991)$ found it again in the same forest and announced the rediscovery of the species. Over the next few years, field researchers suggested that the species had a restricted and patchy distribution (Mittermeier et al. 1994, 2006), but subsequent researchers have recorded its presence in the Mantadia, Masoala, Marojejy, and Verezantsoro National Parks, and the Analamazaotra and Anjanaharibe-Sud Special Reserves (Garbutt 2000; Goodman and Raselimanana 2002; Rakotoarison 1998; Rakotoarison et al. 1996; Schütz and Goodman 1998). 


\section{Mirza Gray, 1870: Dwarf lemur or giant mouse lemur}

Mirza coquereli (Grandidier, 1867): Coquerel's dwarf lemur

Mirza zaza Kappeler and Roos in Kappeler et al., 2005: Northern dwarf lemur

Dwarf lemurs of the genus Mirza are medium-sized, omnivorous, and nocturnal. The preferred mode of locomotion is rapid quadrupedal running. Until recently, primatologists recognized only one species, Mirza coquereli. It was recorded from the western dry forests, in 2 widely separated (several hundred kilometers) subpopulations; one in the north, in the Sambirano region and including the Ampasindava Peninsula, and the other in the central west in the National Park of Zombitse-Vohibasia, south of the Mangoky River, north to Antsalova and Belo-surTsiribihina (Mittermeier et al. 1994, 2006). Petter et al. (1977), Tattersall (1982), and Mittermeier et al. (1994) suggested that Mirza may occur between the 2 areas. Recent surveys found Mirza cf. coquereli at Namoroka, between the 2 areas (Kappeler et al. 2005).

Alfred Grandidier (1867) originally described Mirza coquereli in Cheirogaleus, indicating its resemblance to the fork-marked lemur, known to Grandidier as $C$. furcifer. At ca. $300 \mathrm{~g}$, the slightly smaller Coquerel's dwarf lemur is $>3$ times the mass of the largest mouse lemur, with which it was previously lumped in Microcebus, based largely on similar features of dental anatomy and locomotive behavior (Petter et al. 1977). Tattersall (1982) revived the genus Mirza for it, citing its larger size and some morphological and behavioral features. The coat of Mirza coquereli is a rich brown or grayish brown, and their ears are large, rounded, and distinctive.

Kappeler et al. (2005) conducted a study of the external morphology and genetics, comparing the southern and northern populations of Mirza. They found Mirza from Kirindy/CFPF (southern) to be heavier and slightly larger than those in the north (Ambato). They concluded that "all external measurements that controlled for differences in body size indicated northern Mirza to be scaled-down versions of the animals from the south" (p.16). The northern Mirza are more grayish than typical Mirza coquereli. Kappeler et al. (2005) found differences in social organization, nesting behavior, and reproductive activity in the 2 Mirza populations (northern Mirza are more promiscuous; Setchell and Kappeler 2003), and genetic studies (mitochondrial cytochrome $b$ ) also clearly separated them. Together they formed a distinct clade from Microcebus, supporting their generic separation by Tattersall (1982). Morondava is the type locality of Mirza coquereli, the correct name for the southern population, and Kappeler and Roos in Kappeler et al. (2005) gave the name Mirza zaza to the northern population, with the type locality being "Baie de Pasandava" (=Ampasindava), Congoni, Province of Antsiranana. Dwarf lemurs are secretive, their distributions need to be further investigated, and further taxa may yet be discovered.

\section{Cheirogaleus É. Geoffroy, 1812: Dwarf lemurs}

Cheirogaleus medius É. Geoffroy, 1812: Eastern fat-tailed dwarf lemur

Cheirogaleus major É. Geoffroy, 1812: Greater dwarf lemur

Cheirogaleus adipicaudatus Grandidier, 1868: Southern fat-tailed dwarf lemur

Cheirogaleus crossleyi Grandidier, 1870: Furry-eared dwarf lemur

Cheirogaleus sibreei Forsyth Major, 1896: Sibree's dwarf lemur 
Cheirogaleus ravus Groves, 2000: Greater iron-gray dwarf lemur

Cheirogaleus minusculus Groves, 2000: Lesser iron-gray dwarf lemur

The dwarf lemurs are small nocturnal primates that range from 150 to $600 \mathrm{~g}$, but also vary considerably in body mass across seasons (Mittermeier et al. 1994, 2006). They employ quadrupedal locomotion along branches at all levels of the forest and tend to jump less and move more slowly than the closely related mouse lemurs (Microcebus spp.). As many as 7 species are now believed to occur throughout Madagascar, but the number will undoubtedly change as soon as the distributions are better defined. Indeed, at this time, it is fair to say that the taxonomy of the genus is by far the most confused of all 15 lemur genera. What we relate here is likely to be substantially modified over the course of the next few years.

Geoffroy St. Hilaire (1812) described Cheirogaleus from 3 drawings of dead specimens that Dr. Philibert Commerçon sent to Paris with no locality information. Geoffroy considered each drawing to represent a distinct species, naming them major, medius, and minor. Wolf (1822) disagreed and assigned all 3 "specimens" to Lemur commersonii. Geoffroy (1828) assigned the first biological specimen of Cheirogaleus to reach Paris, a living individual, to a new species, C. milii. Smith (1833) then added Cheirogaleus typicus to the genus based on a specimen that presumably originated in southeast-central Madagascar. Grandidier (1867) described Chirogalus [sic] samati from the Tsidsibon River of coastal western Madagascar, 2 additional species, $C$. gliroides and C. adipicaudatus, from Tuléar the following year (Grandidier 1868), and 2 yr later C. crossleyi from the "forests east of Antsianak" (Grandidier 1870). Cheirogaleus gliroides was ultimately determined to be a mouse lemur (genus Microcebus), and no type specimens of adipicaudatus or crossleyi remain. Gunther (1875) added Cheirogaleus trichotis to the growing list of dwarf lemurs, but Petter-Rousseaux and Petter (1967) eventually reassigned the species to its own genus, Allocebus. A review of the Cheirogaleidae by Gray (1872) introduced Opolemur to dwarf lemur taxonomy, and Forsyth Major (1894) followed shortly thereafter with descriptions of 2 new species, Opolemur thomasi from Fort Dauphin and Cheirogaleus melanotis from Vohima. Two years later, Forsyth Major (1896) described the "last" new species of dwarf lemur, Chirogale [sic] sibreei from Ankeramadinika "one day's journey east of Antananarivo." The locality is not included in available gazetteers of Madagascar but is depicted on a map published in 1900 (Anonymous 1900). Sabotsy $\left(18.883^{\circ} \mathrm{S}, 47.967^{\circ} \mathrm{E}\right)$ and Manjakandriana $\left(18.917^{\circ} \mathrm{S}, 47.800^{\circ} \mathrm{E}\right)$ are close to Ankeramadinika on the map and are also on a modern map (F.T.M. 1990). By comparing the maps, one can approximate Ankeramadinika to $c a .2 .5 \mathrm{~km}$ east of Ambatolaona $\left(18.933^{\circ} \mathrm{S}\right.$, $\left.47.900^{\circ} \mathrm{E}\right)$.

Elliot (1913) described the new genus Altililemur for the fat-tailed species, and made Opolemur a synonym of Cheirogaleus. In addition, he considered Geoffroy's (1812) names major, medius, and minor to be synonyms of milii, samati, and Microcebus murinus (the gray mouse lemur), respectively. Schwarz (1931) recognized only 2 species, Cheirogaleus medius (with samati as a subspecies) and C. major (with crossleyi as a subspecies), in a single genus. He considered Cheirogaleus minor and $C$. gliroides to be synonyms of Microcebus murinus; Opolemur thomasi to be synonymous with $C$. medius medius; Lemur commersonii, C. milii, C. typicus, and C. adipicaudatus to be synonymous with C. major major; 
and $C$. melanotis and $C$. sibreei to be synonymous with $C$. major crossleyi. Tattersall (1982) and Mittermeier et al. (1994) recognized 2 species of Cheirogaleus-medius and major-but considered each to be subspecifically monotypic. However, Mittermeier et al. (1994) indicated that significant variation in pelage coloration was known from the species, and noted that its geography and taxonomy were poorly understood. Groves (2000) provides a more detailed review of the taxonomic history of Cheirogaleus.

Based on museum specimens, Groves (2000) recently redefined the long-held view of Cheirogaleus taxonomy by resurrecting 2 taxa $(C$. adipicaudatus and $C$. sibreei), elevating $C$. major crossleyi to a full species, and describing 2 new species: C. minusculus and $C$. ravus.

Dwarf lemurs referred to as Cheirogaleus medius occur in forests of west, southwest and southern Madagascar from the Bay of Narinda in the northern part of its range to Fort Dauphin (Tolagnaro) in the south (Petter and Petter-Rousseaux 1979; Tattersall 1982). Tattersall (1982) argued that Cheirogaleus medius samati did not warrant subspecific status. However, he also mentioned that the taxonomic status of specimens collected in the Sambirano region and in northern and eastern Madagascar was problematic. Following Groves' (2000) revision, 2 species are now recognized within the former Cheirogaleus medius. Groves (2000) assigned dwarf lemur specimens from Tabiky (west of Ankazoabo), $170 \mathrm{~km}$ east of Tuléar (Toliara), and from Fort Dauphin to Cheirogaleus adipicaudatus, and specimens from Beroboka, north of Morondava, Tsidsibon River (west coast), and Ampijoroa to $C$. medius. Based on these findings he concluded that Cheirogaleus adipicaudatus occurs in the southern xerophytic bush zone of Madagascar and C. medius in the dry forests of western Madagascar.

Harcourt and Thornback (1990), Mittermeier et al. (1994, 2006), and Tattersall (1982) reported Cheirogaleus major to occur throughout forested areas of eastern Madagascar from Fort Dauphin (Tolagnaro) in the south to Montagne d'Ambre in the north, its range extending westward to include the Tsaratanana Massif and the Sambirano region. Petter et al. (1977) acknowledged the presence of Cheirogaleus major as far west as the Bongolava region near the Manambolo River, and Thalmann (2000a) reported that a preliminary analysis of the population's taxonomic status has been initiated. Petter et al. (1977) also noted a dwarf lemur with more reddish fur north of the Masoala Peninsula but presumed it to be Cheirogaleus major crossleyi, arguing that there was insufficient evidence to recognize a distinct subspecies.

Reddish specimens assigned to Cheirogaleus crossleyi by Groves (2000) originate from Lac Alaotra, Andasibé, and Vohima (Vohemar), which indicates a distribution mainly inland of C. major and extending further north. Cheirogaleus sibreei occurs from Ankeramadinika, described as "one day's journey east of Antananarivo," from Imerina (a region that it apparently shares with $C$. crossleyi) and Ampasindava. Of the 2 new species Groves (2000) described, Cheirogaleus ravus, the larger iron-gray form, has a small coastal range surrounding the type locality of Tamatave and within the distribution of C. major. Cheirogaleus minusculus, the smaller iron-gray form, is known only from the type locality, Ambositra, in central western Madagascar, but Groves hypothesized that dwarf lemurs seen in the forests of the Bongolava Massif by Petter et al. (1977) and Thalmann and Rakotoarison (1994; Thalmann 2000a) would belong to the species. Photos of a dwarf lemur captured and later released on 
the Bongolava Plateau, shown subsequently to Groves by Thalmann, indicate that Cheirogaleus from the locality are not $C$. minusculus but an undescribed species.

Groves' (2000) suggestions for the biogeographic distribution of the different forms may need major revision. Morphological and genetic measures of museum specimens and new samples from the field collected in the region of Fort Dauphin, southeastern Madagascar, revealed a very complex biogeographic distribution of 3 distinct morphotypes of dwarf lemurs. On the basis of these measures, Hapke et al. (2005) assigned the forms in the Fort Dauphin region to Cheirogaleus medius, $C$. major, and C. crossleyi. There, the typical western dry forest species, Cheirogaleus medius, occurs in evergreen littoral rain forest $(>2400 \mathrm{~mm}$ rain/yr) east of Fort Dauphin in sympatry with $C$. major. Cheirogaleus crossleyi was in a remnant patch of evergreen humid rain forest west of Fort Dauphin, in a region Groves (2000) had assumed to consist of spiny bush. This was unexpected because the specimens Groves described as Cheirogaleus crossleyi came from much further north. Combining Groves' (2000) analysis with the information Hapke et al. (2005) collected, Cheirogaleus crossleyi would occur all along the highland and western part of the eastern rain forest belt whereas $C$. major would be more in the eastern (lowland?) portion of the eastern rain forest. Systematic revision with documented and georeferenced specimens is required to resolve the taxonomy and biogeography of the genus.

Ongoing field work on Cheirogaleus indicates that it is highly likely that there will be significant changes in the taxonomy of the genus over the next few years (Groeneveld 2008; Groeneveld et al. 2005).

\section{Phaner Gray, 1870: Fork-marked lemurs}

Phaner furcifer (de Blainville, 1839): Masoala or eastern fork-marked lemur

Phaner pallescens Groves and Tattersall, 1991: Pale or Western fork-marked lemur

Phaner parienti Groves and Tattersall, 1991: Sambirano or Pariente's forkmarked lemur

Phaner electromontis Groves and Tattersall, 1991: Amber Mountain fork-marked lemur

Phaner is discontinuously distributed throughout Madagascar, and had been viewed as a monotypic genus since its description (as Lemur furcifer by de Blainville in 1839). The relatively large, nocturnal cheirogaleid lemurs are very vocal and display a characteristic locomotion, running rapidly along horizontal tree branches and jumping from one to the next without pausing, and performing unusual headbobbing movements that immediately distinguish them in the field (Mittermeier et al. 1994, 2006). Groves and Tattersall (1991) examined variations in pelage color and pattern and body size and proportions among geographically distinct populations, which led to the recognition of 4 subspecies: Phaner furcifer furcifer, $P$. f. pallescens, P. f. parienti, and P. f. electromontis. More recently, Groves (2001) acknowledged that they are discrete and elevated them to full species.

Phaner furcifer occurs on the Masoala Peninsula and possibly adjacent portions of the mainland in northeast Madagascar (Groves and Tattersall 1991). According to Mittermeier et al. (1994), isolated populations from the Betampona and Zahamena Nature Reserves further south may also be referable to this taxon, if not a new one. 
Phaner pallescens occur in western Madagascar along a narrow strip from just south of the Fiherenana River, including the Forêts de Mikea (Ganzhorn and Randriamanalina 2004) north to the region of Soalala (Groves and Tattersall 1991). An isolated population of uncertain taxonomic affinity occurs in Andohahela, Parcel II. A specimen from the Namoroka Special Reserve has a larger body and shorter tail than fork-marked lemurs from the Morondava region, and may represent a distinct taxon. Phaner parienti occurs in the Sambirano region of northwest Madagascar south of Ambanja, including the Ampasindava Peninsula and extending south to the Andranomalaza River. The larger Phaner electromontis evidently has a restricted distribution, being confined largely to the vicinity of Montagne d'Ambre. Mittermeier et al. (2006) also noted the presence of Phaner in the forests near Daraina, and suggested that it might be another population of P. electromontis or perhaps a new species. Subsequent observations by S. M. Goodman (pers. comm.) also indicate that it may be yet another species. We follow Groves $(2001,2005)$ in recognizing the 4 named Phaner as distinct species, pending further revisions that are almost certain to include descriptions of new species.

\section{Family Lepilemuridae Gray, 1870}

Mittermeier et al. (1994) and Groves (2001) placed Lepilemur in the Megaladapidae, with 2 subfamilies, Lepilemurinae and Megaladapinae, the latter represented by the extinct genus Megaladapis. However, recent analysis of the cytochrome $b$ gene from bones of Megaladapis suggests that it is an independent long branch within the lemuriform radiation and not the sister group to Lepilemur (cf. Yoder et al. 1999b). As a result, Groves (2005) placed Lepilemur in the Lepilemuridae, attributing the authorship of the family-group name to Gray (1870), following a personal communication from Ian Tattersall, rather than to Stephan and Bauchot (1965) as in Groves (2001). The number of species recognized in the genus has increased considerably in recent years, more so than in any other group of primates; 15 new species were described in 2006 alone.

\section{Lepilemur I. Geoffroy, 1851: Sportive or weasel lemurs}

Lepilemur mustelinus I. Geoffroy, 1851: Weasel lemur

Lepilemur microdon (Forsyth Major, 1894): Small-toothed sportive lemur Lepilemur leucopus (Forsyth Major, 1894): White-footed sportive lemur

Lepilemur ruficaudatus Grandidier, 1867: Red-tailed sportive lemur

Lepilemur edwardsi (Forbes, 1984): Milne-Edwards' sportive lemur Lepilemur dorsalis Gray, 1870: Nosy Be or Gray-backed sportive lemur Lepilemur septentrionalis Rumpler and Albignac, 1975: Northern sportive lemur Lepilemur ankaranensis Rumpler and Albignac, 1975: Ankarana sportive lemur Lepilemur aeeclis Andriaholinirina et al., 2006: Antafia sportive lemur

Lepilemur randrianasoli Andriaholinirina et al., 2006: Randrianasolo's sportive lemur

Lepilemur sahamalazensis Andriaholinirina et al., 2006: Sahamalaza Peninsula sportive lemur

Lepilemur mittermeieri Rabarivola et al., 2006: Mittermeier's sportive lemur 
Lepilemur ahmansoni Louis et al., 2006: Ahmanson's sportive lemur

Lepilemur betsileo Louis et al., 2006: Betsileo sportive lemur

Lepilemur fleuretae Louis et al., 2006: Fleurette's sportive lemur

Lepilemur grewcocki Louis et al., 2006: The Grewcock's sportive lemur

Lepilemur hubbardi Louis et al., 2006: Hubbard's sportive lemur

Lepilemur jamesi Louis et al., 2006: James' sportive lemur

Lepilemur milanoii Louis et al., 2006: Daraina sportive lemur

Lepilemur petteri Louis et al., 2006: Petter's sportive lemur

Lepilemur seali Louis et al., 2006: Seal's sportive lemur

Lepilemur tymerlachsoni Louis et al., 2006: Hawks' sportive lemur

Lepilemur wrighti Louis et al., 2006: Wright's sportive lemur

Lepilemur otto Craul et al., 2007: Otto's sportive lemur

Lepilemur scottorum Lei et al., 2008: The Scott's sportive lemur

Lepilemur is a genus of medium-sized, nocturnal lemurs occurring in virtually all forested areas of Madagascar's periphery. They usually weigh less than $1 \mathrm{~kg}$, and are vertical clingers and leapers, with long lower limbs compared to their trunk and forelimbs. In appearance, Lepilemur could be confused with the indriid Avahi, but they are usually smaller, have more prominent ears, and lack the highly visible white patches on the back of the thighs that are so typical of Avahi.

Schwarz (1931) and Hill (1953) recognized only 2 species of Lepilemur: L. mustelinus from the eastern forests and L. ruficaudatus from western and southern Madagascar, the latter with 2 subspecies, ruficaudatus and leucopus. Petter and Petter-Rousseaux (1960) subsequently recognized a single species, mustelinus, with 5 subspecies (mustelinus, microdon, ruficaudatus, leucopus, and dorsalis). Petter et al. (1977) later increased the number of species to 7-dorsalis, edwardsi, leucopus, microdon, mustelinus, ruficaudatus, septentrionalis-with the last having 4 subspecies (Rumpler and Albignac 1975). Groves (2001) noted that 2 of the subspecies of Lepilemur septentrionalis are not geographically separate, as is required for subspecies, and reduced the number to 2: L. s. septentrionalis (with sahafarensis Rumpler and Albignac, 1975, as a junior synonym) and L. $s$. ankaranensis (with andrafiamenensis Rumpler and Albignac, 1975, as a junior synonym).

Tattersall (1982) followed the classification of Petter and Petter-Rousseaux (1960), recognizing only 1 species, Lepilemur mustelinus, but with 6, not 5, subspecies (dorsalis, edwardsi, leucopus, mustelinus, ruficaudatus, septentrionalis), adding the forms edwardsi and septentrionalis, but not recognizing microdon. However, a cytogenetic study by Andriaholinirina et al. (2005) confirmed that the karyotype of L. microdon differed from those of all other members of the genus, and as such its status as a distinct species. Jenkins (1987) later recognized the 7 species Petter et al. (1977) proposed, but no subspecies, an arrangement followed by Mittermeier et al. (1994). On the basis of cytogenetic and molecular data, the subspecies of Lepilemur septentrionalis listed by Groves (2001) was elevated to species: L. ankaranensis (cf. Ravaoarimanana et al. 1999, 2004; Rumpler et al. 2002). Groves (2005) and Mittermeier et al. (2006), therefore, listed 8 species of sportive lemurs, all of them cytogenetically distinct (Andriaholinirina et al. 2005; Rumpler and Albignac 1978; Rumpler et al. 2001; Thalmann and Ganzhorn 2003;). Since these publications, 3 molecular genetic studies (Andriaholinirina et al. 2006a; 
Louis et al. 2006b; Rabarivola et al. 2006) have added a further 15 species, making it, with 23 species, the most diverse lemur genus.

The geographic distribution and the distinction between Lepilemur microdon and L. mustelinus given in the field guide by Mittermeier et al. (1994) were incorrect. According to Petter et al. (1977), Lepilemur microdon occurs in the humid forests of southeastern Madagascar, ranging from the Onibe River at the northern extent of its range south to near (west of) Tolagnaro (Fort Dauphin). Groves (2001), citing Jenkins (1987), contended that L. microdon occurs in southeastern Madagascar from $18^{\circ} \mathrm{S}$ to $24^{\circ} 50^{\prime} \mathrm{S}$, and is sympatric with L. mustelinus south of Toamasina (Tamatave). North of the Onibe River up to the forests of Tsaratanana and Andapa, Lepilemur microdon is replaced by L. mustelinus (cf. Petter et al. 1977). Groves (2001), again citing Jenkins (1987), identified the distribution of Lepilemur mustelinus as extending from $13^{\circ} 45^{\prime} \mathrm{S}$ in the north, which is in agreement with Tattersall (1982), but only as far south as $20^{\circ} \mathrm{S}, \mathrm{ca}$. $500 \mathrm{~km}$ north of Tolagnaro (Fort Dauphin). Lepilemur mustelinus is a relatively large member of the genus, essentially brown and often with a grayish head. Its diploid chromosome number is 34 (Rumpler and Albignac 1978; Rumpler et al. 1986). Lepilemur microdon differs from L. mustelinus in having a redder-brown dorsal surface, a dark and more pronounced median dorsal stripe, and yellower flanks, as well as smaller cheek teeth and a white patch of fur on the neck extending laterally (Petter et al. 1977; N. Andriaholinirina, pers. comm.). The diploid chromosome number of Lepilemur microdon is 24 (Andriaholinirina et al. 2005).

Lepilemur leucopus is a smaller, lighter-colored, larger-eared, longer-tailed member of the genus, and has a diploid chromosome number of 36 (Petter et al. 1977). It occurs in the dry Didiereaceae bush and gallery forests of southern and southwestern Madagascar as far north as the Onilahy River (Mittermeier et al. 1994; Petter et al. 1977; Sussman and Richard 1986; Tattersall 1982).

Lepilemur ruficaudatus is intermediate in size between the smaller L. leucopus, with which it shares prominent ears, and the larger L. mustelinus and L. microdon (cf. Groves 2001), and is distinguished from other members of the genus by its reddish tail. It has a diploid chromosome number of 20. Lepilemur ruficaudatus was formerly believed to have a large range in western Madagascar: the Onilahy River marking the southern boundary and the Betsiboka River the northern boundary (Bachmann et al. 2000; Mittermeier et al. 1994; Tomiuk et al. 1997; Zaramody et al. 2005). Thalmann (2000b) indicated it might be sympatric in Bemaraha with an undescribed form of Lepilemur. Andriaholinirina et al. (2006a, b) later described Lepilemur randrianasoli from Bemaraha, but without mentioning whether $L$. ruficaudatus occurred there also. Pastorini et al. (2003) suggested that the forms either side of the Tsiribihina River were different species. Andriaholinirina et al. (2006a) confirmed their suspicion, describing Lepilemur randrianasoli as occurring north of Tsiribihina River, possibly to the Manambaho or Mahavavy du Sud rivers. The range of Lepilemur ruficaudatus is possibly now limited to the south of the Tsiribihina River, south to the Onilahy River, where it is replaced by Lepilemur leucopus (cf. Mittermeier et al. 2006).

Lepilemur edwardsi is slightly smaller and longer-tailed than L. ruficaudatus, and occurs to its north in western Madagascar (Petter et al. 1977). New data suggest that the southern limit of its distribution is the Betsiboka River, from which it extends 
north as far as the Bay of Mahajamba (Zaramody et al. 2005). Previous reports of Lepilemur edwardsi south to the Tsiribihina River might be based on erroneous sampling (Petter et al. 1977; Tattersall 1982). The diploid chromosome number of $L$. edwardsi is 22. Molecular data based on 3 individuals suggest that Lepilemur edwardsi could be split into 2 full species north and south of the Betsiboka River (Pastorini et al. 2003). Andriaholinirina et al. (2006a) described L. aeeclis from the north of the Betsiboka River.

Lepilemur dorsalis is a small sportive lemur, with small ears and a very long tail (Groves 2001). Its range was thought to extend from the Sambirano region of northwestern Madagascar, including the Ampasindava Peninsula and the islands of Nosy Be and Nosy Komba (Mittermeier et al. 1994, 2006). To the south it occurs as far as the Ankarafa Forest on the Sahamalaza Peninsula (Randriatahina and Rabarivola 2004). However, in their description of Lepilemur sahamalazensis, Andriaholinirina et al. (2006a) restrict L. dorsalis to Nosy Be, Ambanja and regions north of the Sambirano River, probably to the Mahavavy du Nord River, and the range of $L$. ankaranensis. Lepilemur sahamalazensis and L. dorsalis are the only sportive lemurs to have a diploid chromosome number of 26 (Andriaholinirina et al. 2006a).

Lepilemur ankaranensis, slightly larger and even longer-tailed than L. dorsalis, is the most northerly member of Lepilemur. Forms occurring in both dry deciduous and humid forests that extend from Montagne d'Ambre southward to the Mahavavy River near Ambilobe and eastward at least as far as the Manambato River, and probably to the Fanambana River, north of Sambava, have been assigned to this taxon. The diploid chromosome number for the species ranges from 36 to 38 (Ravaoarimanana et al. 2004; Rumpler et al. 2001). Andriaholinirina et al. (2006a) found that Lepilemur ankaranensis was more closely related to L. dorsalis than to L. septentrionalis.

Lepilemur septentrionalis is restricted to the small dry deciduous forests of Sahafary, Madirobe and Andrahona, north of the Irodo River. The diploid chromosome number for the species ranges from 34 to 36 (Ravaoarimanana et al. 2004; Rumpler et al. 2001).

Andriaholinirina et al. (2006a) conducted a comparative cytogenetic and molecular genetic (cytochrome $b$ gene; 1140 base pairs) study of the 8 sportive lemurs recognized by Groves (2005) and Mittermeier et al. (2006), focusing particularly on their taxonomy and phylogenetic relationships. They confirmed the validity of the 8 species, but identified what they referred to as "cryptic speciation events" within Lepilemur ruficaudatus (3 genetically distinct populations; one north, the other south of Tsiribihina, and a third south of Betsiboka) and L. dorsalis (one from Sahamalaza, the other from Ambanja/Nosy Be), which resulted in the description of a further 3 species. Lepilemur aeeclis is now the sportive lemur that occurs between the Betsiboka and Mahavavy du Sud rivers, and possibly south of the latter. Lepilemur randrianasoli occurs from the type locality of Andramasay, Province of Toliary, and Bemaraha, western Madagascar, with the Tsiribihina River probably marking the southern limit and the Manambaho or Mahavavy du Sud rivers possibly marking the northern limit to its range. Lepilemur randrianasoli, L. aeeclis, and L ruficaudatus share the same diploid chromosome number of 20 (Andriaholinirina et al. 2005, 2006a). The diminutive Lepilemur sahamalazensis is the form on the Sahamalaza Peninsula, Province of Mahajanga, with the Sambirano River being the likely northern boundary to its range and the Maevarano River the southern limit. 
Further research on the lemurs of the Ampasindava Peninsula in the northwest resulted in the discovery of an enclave of sportive lemurs (diploid chromosome number $2 n=24$ ) within the range of L. sahamalazensis. (Note that the map [Fig. 1] of Rabarivola et al. [2006] has evidently switched the ranges depicted for Lepilemur dorsalis and L. sahamalazensis.) Rabarivola et al. (2006) described the lemurs with the name Lepilemur mittermeieri. The full extent of their range is unknown, but restricts even further that of its sister species, Lepilemur sahamalazensis.

Another major study of the diversity of the genus, using molecular genetics and morphological analyses, resulted in the description of 11 more species (Louis et al. 2006b). Three of them are from the northwest. Lepilemur tymerlachsoni, a light brownish-gray sportive lemur, was described as the form on the island of Nosy Be, formerly thought to be the domain of L. dorsalis, which is now restricted to the mainland. Lepilemur ahmansoni occurs west of the lower Mahavavy du Sud River; it is smaller than L. aeeclis, mainly dark gray, but with a reddish-brown color on the back. Its range limits with Lepilemur randrianasoli to the south of it are uncertain. The large $(1.1 \mathrm{~kg})$ Lepilemur grewcocki from the Anjigmangirina Classified Forest, Province of Mahajanga, occurs north of the Mahajamba River and south of Maevarano and Sofia rivers, an area thought to have been occupied by L. edwardsi.

Two of the species Louis et al. (2006b) described are from the northeast. The light chocolate-brown to reddish-brown Lepilemur seali from Anjanaharibe-Sud Special Reserve, Province of Antsiranana, occupies the northern part of the range formerly attributed to Lepilemur mustelinus. In discussing the range of Lepilemur ankaranensis, Mittermeier et al. (2006) suggested that the form in Daraina was a distinct species. Louis et al. (2006b) found it was, and named it Lepilemur milanoii, which is reddish brown on the back and grayish-white on the venter. Louis et al. (2006b) recorded DNA sequences identical to those of the latter species within the range of Lepilemur ankaranensis, and the potential sympatry needs further investigation.

Louis et al. (2006b) described 2 new forms from the southwest. Lepilemur hubbardi occurs in the Zombitse National Park, Province of Toliara, south of the middle Mangoky River, within the range formerly believed to have belonged to $L$. ruficaudatus. Lepilemur petteri occurs farther south, south of the Onilahy River at Beza-Mahafaly, in a part of the range previously ascribed to L. leucopus (cf. Mittermeier et al. 2006).

The remaining 4 of the species described by Louis et al. (2006b) occur in the southern and southeastern forests. The large Lepilemur betsileo from Fandriana Classified Forest, Province of Fianarantsoa, occurs between the Mangoro and Namorona rivers. Lepilemur fleuretae occurs in the Andohahela National Park in the Manangotry region between the Mandrare River (in the west) and the Mananara River (in the north). Lepilemur jamesi occurs south of Manampatrana River and north of the Mananara River. Louis et al. (2006b) collected it in Manombo Special Reserve. A comparative cytogenetic and molecular study by Andriaholinirina et al. (2006b) confirmed the distinctiveness of Lepilemur jamesi, and aligned it most closely to L. mustelinus even though the 2 species are separated geographically by L. microdon. Finally, the type locality of Lepilemur wrighti is Kalambatritra Special Reserve, Province of Toliara, and Louis et al. (2006b) believe that it ranges from the west of the Mananara River and north of the Mandrare River (Rabeson et al. 2006). 
Craul et al. (2007) described 2 species of Lepilemur: Lepilemur otto from Ambodimahabibo and L. manasamody from Ambongabe, Province of Mahajanga, Madagascar. They suggested that the latter may be a junior synonym of Lepilemur grewcocki Louis et al., 2006, as did Zinner et. al. (2007). Lei et al. (2008) described Lepilemur scottorum from the Masoala National Park, Province de Antsiranana.

As listed by Tattersall (1982), Jenkins (1987), and Groves (2001), several mainly 19 th century nomina have in the 20th century been relegated to synonymy, and appear to have been overlooked in recent revisions. It is essential that all the type specimens be examined, and if possible DNA extracted from them by Ancient DNA specialists to determine whether all currently-used names are indeed applicable to the populations to which they have become restricted, and whether any of the supposed older synonyms actually represent earlier names for some of the recently described species.

The recent documentation of the extraordinary genetic diversity of Lepilemur has major consequences for understanding the conservation status of the 8 species described and illustrated in Mittermeier et al. (2006). Lepilemur edwardsi and L. dorsalis in the northwest, and most especially L. ruficaudatus of the western dry forests, L. leucopus in the south, and L. microdon and L. mustelinus of the eastern forests, have as a result of these discoveries, very much smaller geographic ranges. Notable is the diversity in the far north of Madagascar and, with their minute ranges, conservationists should consider Lepilemur septentrionalis, L. ankaranensis, $L$. dorsalis, L. milanoii, L. mittermeieri, L. tymerlachsoni, and L. sahamalazensis among the most endangered primates in the world.

Having said this, it should be noted that Zinner et al. (2007) question the validity of several of the newly described Lepilemur spp. Their genetic analyses revealed genetic distances between some of the newly named species that are within the intraspecific instead of interspecific variation. Zinner et al. (2007) examined conflicting results for the sportive lemurs in northwest Madagascar, those within the range of what was once considered to be Lepilemur dorsalis. Because the type localities of Lepilemur dorsalis Gray, 1870 and L. grandidieri (Forsyth Major, 1894) were both "Northwest Madagascar," the proper name of 1 or 2 of the new species from the region (sahamalazensis, grewcocki, mittermeieri, tymerlachsoni) could be either of them. Researchers have not identified the true dorsalis, as such, and have made no attempt to identify grandidieri, formerly a junior synomym of dorsalis. Genetic analyses of the holotypes of dorsalis and grandidieri are needed to resolve this. Therefore, Zinner et al. (2007) indicated that tymerlachsoni or mittermeieri might be junior synonyms. They also indicated that Lepilemur manasamody Craul et al., 2007 is probably a junior synonym of L. grewcocki Louis et al., 2006 - sampling sites were $<2 \mathrm{~km}$ apart, with no evident geographic barrier — but "further testing is necessary" (p.55). Under any circumstance, Zinner et al. (2007, p. 55) concluded that "the number of species in NW Madagascar is rather less than it had seemed to be as of May, 2007."

\section{Family Lemuridae Gray, 1821}

The Lemuridae contains 5 living genera: Lemur, Eulemur, Varecia, Hapalemur, and Prolemur and the extinct genus Pachylemur. Molecular data confirm the inferences from morphology that Lemur and Hapalemur are sister genera and form an exclusive 
clade. The Lemuridae range in body mass from $700 \mathrm{~g}$ to $4.5 \mathrm{~kg}$. Forelimbs are slightly shorter than hind limbs, and typical locomotor patterns include quadrupedalism and leaping. Groves (2001) noted that all of the Lemuridae have at least spotty pigmentation of the ocular fundus, which tends to obscure the golden shine produced by the tapetum lucidum (Pariente 1970).

\section{Hapalemur I. Geoffroy, 1851: Bamboo or gentle lemurs}

Hapalemur griseus (Link, 1795): Gray bamboo lemur

Hapalemur occidentalis Rumpler, 1975: Western bamboo lemur, Sambirano bamboo lemur

Hapalemur alaotrensis Rumpler, 1975: Lac Alaotra bamboo lemur

Hapalemur meridionalis Warter et al., 1987: Southern bamboo lemur

Hapalemur aureus Meier et al., 1987: Golden bamboo lemur

Hapalemur gilberti Rabarivola et al., 2007: Gilbert's bamboo lemur

Though it is clear that the genus Hapalemur belongs in the Lemuridae, uncertainty remains regarding its relationship to the other genera. Behavioral and genetic evidence as well as morphology indicate that Hapalemur forms a clade with Lemur to the exclusion of Eulemur (cf. Groves 2001; Macedonia and Stanger 1994; Montagnon et al. 1993; Yoder 1997). We recognize 5 species of Hapalemur. All are medium to small, have moderately long hind limbs, prefer vertical resting postures, and leap readily between closely-spaced vertical supports. All have relatively blunt faces with short muzzles. Coloration is essentially gray, and activity occurs around dusk (Mittermeier et al. 1994). As in Lemur, Hapalemur has brachial and antebrachial glands (Affolter 1938; Ralison 2004). Groves (2001) recently removed the greater bamboo lemur, formerly known as Hapalemur simus, and returned it to its own genus, Prolemur.

Tattersall (1982) described some minor confusion in the taxonomic history of Hapalemur griseus. He listed 3 subspecies: griseus, occidentalis, and alaotrensis. The nominate subspecies corresponds to 1 of the 2 species given by I. Geoffroy in 1851, the other being Hapalemur olivaceus. The former was based on his father's Lemur griseus (E. Geoffroy, 1796), a species that had actually been given the same name a year before by Link, based on the same specimen. Subsequent authors tended to regard Hapalemur olivaceus as a junior synonym. Rumpler (1975) established occidentalis and alaotrensis as subspecies in advance of the publication by Petter et al. (1977), which also described alaotrensis as a new subspecies of griseus and credited Rumpler and Albignac (1973) with the description of Hapalemur griseus occidentalis. Warter et al. (1987) added the subspecies meridionalis based on cytogenetic studies of specimens from extreme southern Madagascar.

Groves (2001) elevated both occidentalis and alaotrensis to full species, retaining only griseus and meridionalis as subspecies of Hapalemur griseus. Subsequent cytogenetic and molecular studies based on cytochrome $b$ and 12S mtDNA, covering samples extending from the north to the south of eastern Madagascar carried out by Fausser et al. (2002), Rumpler et al. (2002), and Pastorini et al. (2002) did not confirm the arrangement, but instead regrouped Hapalemur occidentalis as a subspecies of $H$. griseus. Rumpler et al. (2002) also reported an extension to the range of Hapalemur griseus occidentalis to the east at least as far as Maroantsetra and even as far as the National Park of Zahamena (C. Rabarivola, pers. comm.). 
Rumpler et al. (2002) identified two new variants in the area of RanomafanaKianjavato, within what Groves (2001) considered to be $H$. griseus. These $H$. griseus ssp. 1 and ssp. 3 were characterized by their karyotypes, which deviated from what is considered normal for $H$. (g.) griseus, and there was a "hybrid" karyotype between them in addition. They also identified a further new karyotype, which they called ssp.2, in an individual from Tsimbazaza Park Zoo. More recently, Rabarivola et al. (2007) have identified "ssp.2" in the wild, in two specimens from Beanamalao, describing it as a new subspecies, H. g. gilberti, and united Rumpler et al.'s (2002) "sspp.1 \& 2" into a second new subspecies, H. g. ranomafanensis. Inspection of the characters ascribed to these two new taxa suggests to one of us (CPG) that the first of these differs clearly (on the available evidence) from other Hapalemur, and should rank as a distinct species, Hapalemur gilberti, although the second needs more careful investigation to determine whether it is truly distinct from $H$. griseus or simply denotes populations of the latter possessing chromosome polymorphism. In any case, the range of the true $H$. griseus appears now more restricted than was previously described.

The very short genetic distances found between $H . g$. alaotrensis and $H . g$. griseus by Fausser et al. (2002), and Pastorini et al. (2002) were considered by the latter, who assumed a form of what is now called the Genetic Species Concept (see above), to support combining these two groups into a single subspecies. Considering the significant differences in body size and the differences in the content of heterochromatin found in both karyotypes, however, Fausser et al. (2002) and Rumpler et al. (2002) proposed maintaining both as separate subspecies, and as according to the available evidence the Alaotra taxon is diagnosably distinct, we maintain it as a full species. In Rumpler et al.'s analyses all $H$. g. meridionalis cluster together and are separated from the other $H$. griseus subspecies by distances in the range of those observed between species. They therefore, again assuming a Genetic Species Concept, proposed raising this group to specific rank as $H$. meridionalis.

Hapalemur griseus occurs throughout the remaining forests of eastern Madagascar from the Tsaratanana Massif and an area south of Maroantsetra in the far north to Fort Dauphin in the far south (Tattersall 1982). The relatively continuous distribution is broken only around Lac Alaotra where Hapalemur alaotrensis occurs. Hapalemur meridionalis is known only from the region between Fort Dauphin and Andohahela; Rabarivola et al. (2007) recorded what they identified as a hybrid between it and their new subspecies $H$. g. ranomafanensis from Atsimo, just to the south of Ranomafana, so this may mark the boundary between them. H. meridionalis evidently differs from $H$. griseus by being darker/more reddish in color and having a shorter tail (Warter et al. 1987; Mittermeier et al. 1994; Groves 2001; Fausser et al. . 2002), but more morphological data, in addition to further karyotype data, are urgently needed for the geographic limits of $H$. meridionalis and $H$. griseus to be satisfactorily worked out.

Hapalemur occidentalis occurs in several widely separated forested regions of western Madagascar, including the Sambirano region from south of Maromandia north through Beramanja, and the Antsalova/Lake Bemamba region between Maintirano and Belo-sur-Tsiribihina (Mutschler and Tan 2003; Tattersall 1982). Hawkins et al. (1990) also reported a population of what might be Hapalemur occidentalis from the Ankarana Massif in the far north, but its taxonomic status has 
yet to be confirmed. However, Rumpler et al. (2002) described a karyotype characteristic for Hapalemur occidentalis near Maroantsetra, while Rabarivola et al. (2002) found the same karyotype in the Hapalemur from the Zahamena National Park. The mtDNA analyses agreed with the cytogenetic data suggesting a large extension of Hapalemur occidentalis in the eastern region. Hapalemur occidentalis differs in diploid chromosome number $(2 n=58)$ from $H$. griseus and $H$. alaotrensis (2n=54; Rumpler and Albignac 1973).

Hapalemur alaotrensis, significantly larger than either $H$. griseus or $H$. occidentalis (cf. Tattersall 1982; Vuillaume-Randriamanantena et al. 1985), occurs only in the reed beds surrounding Lac Alaotra, the island's largest lake in eastcentral Madagascar. Apparently, it also previously occurred at Andilamena $c a$. $60 \mathrm{~km}$ north of Lac Alaotra, but any populations there were extirpated after the completion of 2 hydroelectric projects in the late 1950s (Mittermeier et al. 1994).

Hapalemur aureus is similar in size to H. alaotrensis and is distinguished from other members of the genus by having a golden-yellow face ring that extends to the cheeks and throat. Molecular data strongly support it being a full species (Pastorini et al. 2002). Its diploid chromosome number is 62 (Rumpler et al. 1991). Hapalemur aureus was discovered in 1986 (Meier and Rumpler 1987; Meier et al. 1987) in rain forests of southeastern Madagascar that were subsequently made part of Ranomafana National Park. Its range has been extended south since then to include portions of the Andringitra National Park as well as the corridor between the 2 reserves (Goodman et al. 2001; Rakotondravony and Razafindramahatra 2004; Sterling and Ramarason 1996) and possibly northeast to the region of Betsakafandrika (Lehman and Wright 2000). It is sympatric with Hapalemur griseus throughout its limited range. The diet of Hapalemur aureus consists largely of new shoots of the giant bamboo (Cephalostachium viguieri) (Meier et al. 1987; Tan 1999; Wright et al. 1987).

\section{Prolemur Gray, 1871: Greater bamboo lemur}

Prolemur simus (Gray, 1871): Greater bamboo lemur; broad-nosed gentle lemur

Tattersall (1982) synonymized Prolemur with Hapalemur, but Groves (2001) pointed to a long list of differences in craniodental features, originally presented by Vuillaume-Randriamanantena et al. (1985), that he believed were sufficient to distinguish Prolemur as a separate genus. Cytogenetic data provided by Rumpler and Dutrillaux (1978) evidently support this view, as do behavioral data from Stanger-Hall (1997) and Macedonia and Stanger (1994) that demonstrate that Prolemur is less closely related to either Hapalemur or Lemur than Hapalemur and Lemur are to each other. We therefore place simus in a monotypic genus, for which the name Prolemur Gray, 1871 is available.

Prolemur simus is much larger than any member of Hapalemur, although it is similarly colored. Evidence from subfossil remains indicates that it was once widespread in Madagascar (Godfrey and Vuillaume-Randriamananatena 1986; Godfrey et al. 2004; Tattersall 1982; Wilson et al. 1988). Today the species survives in forests of eastern Madagascar in the regions of the Andringitra National Park, Ranomafana National Park, and the corridor between the 2 parks, in Karianga, northwest of Manombo (Mittermeier et al. 1994; Sterling and Ramarason 1996; E. E. Louis, unpubl. data). Its range has been extended from the southern localities at least to the central part of the eastern rain forest in the region of Andasibe/Perinet 
around the Torotorofotsy marshes and in the forest of Maromizaha (Dolch et al. 2004, 2008; Rakotosamimanana et al. 2004; Wright et al. 2008). In this region, some individuals lack the characteristic tufted ears, even though they are larger in size than Hapalemur griseus (cf. Johann 1997).

\section{Lemur Linnaeus, 1758: Ring-tailed lemur}

Lemur catta Linnaeus, 1758: Ring-tailed lemur

Lemur, as originally proposed by Linnaeus in the 10th edition of his Systema Naturae (1758), contained 3 species: L. catta (the ring-tailed lemur), L. tardigradus (the slender loris, now a member of the Lorisidae), and L. volans (the Philippine colugo, a member of Dermoptera). Until the late 1980s, Lemur included 6 species: catta, coronatus, fulvus, macaco, mongoz and rubriventer. However, analyses by Simons and Rumpler (1988) and Groves and Eaglen (1988) established Lemur catta as a monotypic taxon and placed the others in a separate genus, Eulemur.

Lemur catta is the only surviving semiterrestrial, diurnal lemur in Madagascar. It is unquestionably the best known, most intensively studied, and the easiest lemur to identify owing to the prominent black-and-white bands along the entire length of its long tail (Jolly 2004). It is a medium-sized species with an adult body mass of $\leq 2.2 \mathrm{~kg}$. The back is gray to rosy brown, the limbs and haunches are gray, and the crown and the neck are dark gray. The underside is white. The face is white except for dark triangular eye patches and a black nose. The ears are angular with white hair on top. Both sexes possess distinctive antebrachial glands above the wrist, which are used for scent-marking. In males, the glands are overlaid with a horny spur. In addition, there is a voluminous sebaceous brachial gland, as in Hapalemur (cf. Andriamiandra and Rumpler 1968; Ralison 2004).

Ring-tailed lemurs live in a wide variety of habitats in south and southwestern Madagascar. Their range extends west from Fort Dauphin, near the southern tip of the island, as far north as the Marofihitse Forest/Kirindy-Mitea, ca. $60 \mathrm{~km}$ south of Morondava on the central western coast (Goodman and Raselimanana 2003; Sussman et al. 2003; Zinner et al. 2001). An additional population occurs on the Andringitra Massif on the southeastern plateau (Goodman and Langrand 1996). Goodman and Langrand (1996) noted that the Andringitra population occurs at higher elevations ( $c$. $2000 \mathrm{~m})$ than other populations of Lemur catta, and that individuals are darker and have fewer tail rings. Yoder et al. (1999a) suggested that, though ecologically distinct, the population did not represent a distinct species. However, along with Groves (2001), they offered this as evidence for possible subspecies within Lemur catta and suggested that further research is needed.

\section{Eulemur Simons and Rumpler, 1988: True lemurs}

Eulemur macaco (Linnaeus, 1766): Black lemur

Eulemur flavifrons (Gray, 1867): Sclater's lemur

Eulemur fulvus (É. Geoffroy, 1812): Brown lemur

Eulemur sanfordi (Archbold, 1932): Sanford's lemur

Eulemur albifrons (É. Geoffroy, 1796): White-fronted lemur

Eulemur rufus (Audebert, 1799): Red lemur

Eulemur rufifrons (Bennett, 1833): Red-fronted lemur

Eulemur collaris É. Geoffroy, 1812: Red-collared lemur 
Eulemur cinereiceps (Grandidier and Milne Edwards, 1890): Gray-headed lemur

Eulemur coronatus (Gray, 1842): Crowned lemur

Eulemur rubriventer (I. Geoffroy, 1850): Red-bellied lemur

Eulemur mongoz (Linnaeus, 1766): Mongoose lemur

Simons and Rumpler (1988) resurrected the name Eulemur, first published by Haeckel in 1895, and used it for all the species and subspecies other than Lemur catta that previously had been included in Lemur. As defined by Simons and Rumpler, it included the species fulvus (with 6-7 subspecies), macaco (with 2 subspecies), coronatus, rubriventer, and mongoz. As many as 7 subspecies have been recognized for Eulemur fulvus, including fulvus, rufus, albifrons, cinereiceps (formerly albocollaris), collaris, sanfordi, and mayottensis. The last-mentioned is a population established outside Madagascar on islands of the Comores, most likely by humanassisted introduction (Tarnaud and Simmen 2002; Tattersall 1982). Mittermeier et al. (1994) considered the introduced Mayotte populations to be Eulemur fulvus fulvus, and did not recognize them as a distinct taxon. Most other authors agree, backed up by genetic data (Pastorini et al. 2000). Recent field observations by Mittermeier indicate that the population is more than likely a hybrid swarm, with great variety in the phenotypes of the individuals at several field sites. Probably the origin of the population included representatives of Eulemur fulvus and other members of the group. Most recently, Groves (2001) elevated all Eulemur fulvus sspp. to full species, based on their distinct external appearances and craniodental characters (Tattersall and Schwarz 1991), as well as recent evidence for unique DNA sequences in $E$. collaris and E. albocollaris (cf. Djlelati et al. 1997; Wyner et al. 1999). Johnson et al. (2008) concluded that albocollaris is a junior synonym for cinereiceps. We follow the arrangement here and replace albocollaris by cinereiceps.

All Eulemur species are medium-sized (body mass $1.2-2.5 \mathrm{~kg}$ ), largely employ quadrupedal locomotion, and have cathemeral activity patterns. With the exception of Eulemur fulvus, all also exhibit sexual dichromatism (Mittermeier et al. 1994). Eulemur spp. occur in almost all forested areas of Madagascar except for the spiny forests of the extreme south.

After the elevation of all former Eulemur fulvus sspp. to species (Mittermeier et al. 2006), E. macaco remained the only member of the genus to have two subspecies: E. m. macaco and E. m. flavifrons. Taking into account the consistency of the morphological differences between black lemurs and blue-eyed black lemurs, the retention of the taxonomy seems questionable. We note in addition, for those inclined to follow a form of the Genetic Species Concept, that the pairwise genetic distances between Eulemur macaco macaco and E. m. flavifrons are 68-72 bp, which is in the same range as that between the former Eulemur fulvus subspecies (29-90 bp, according to Pastorini 2000). Moreover, whereas earlier authors suggested a geographical cline in subspecific traits over a relatively large area of their distributional limits (Meyers et al. 1989; Rabarivola et al. 1991), more recent surveys suggest that the zone of hybridization between the 2 taxa is restricted to the northeastern part of the distribution of Eulemur macaco flavifrons (cf. Andrianjakarivelo 2004; Schwitzer et al. 2005, 2006). Based on the findings, and to restore a consistent taxonomy of Eulemur, we consider them to be full species.

Eulemur macaco occurs mainly in the Sambirano region of northwestern Madagascar, the northern limit to its distribution being the Mahavavy du Nord 
River and the southern limit the Sambirano River (Mittermeier et al. 1994). The western part of its range includes the Ampasindava Peninsula, the islands of Nosy Be, Nosy Komba and Nosy Tanikely (where it has been introduced), and the dry forests along the coast northeast of Ambanja, including the peninsula leading to Nosy Faly. The eastern limit is probably high on the Tsaratanana Massif. Eulemur macaco is sympatric with E. fulvus in the Galoka and Manongarivo Mountains (Meyers et al. 1989; Tattersall 1976a). Males of the species are entirely black, and females have a dark dorsal coat that lightens to a deep rust or brown on the sides of the back. The female's face, extremities, and often the tail, are dark. The ears are lavishly tufted with long hair, and both sexes have rust-colored to brown eyes.

Eulemur flavifrons occurs south of the Andranomalaza River near Maromandia southward to the Maevarano River near Befotaka, with the Sandrakota River being the eastern border of its range (Andrianjakarivelo 2004; Randriatahina and Rabarivola 2004). Eulemur flavifrons is distinguished from $E$. macaco by its grayish to blue eyes and nontufted ears in both sexes; female E. flavifrons have a characteristic white forehead and also tend to be lighter colored than female E. macaco.

Populations of what has been described as a variant of Eulemur macaco occur on the southwestern border of the range of the species, $c a .12 \mathrm{~km}$ north of Maromandia (Schwitzer et al. 2006). The ear tufts of both sexes are not as pronounced as in the Eulemur macaco that Koenders et al. (1985a, b) and Meyers et al. (1989) depicted, and in the females the head is, except for the black face, completely white. The individuals are homogeneous in coloration across groups and forest fragments, which makes it unlikely that they are hybrids. Investigations of these populations are needed, and it seems likely that they may be an undescribed taxon.

Recognizing all members of Eulemur fulvus as species, E. fulvus is the only member of the genus in which males are essentially indistinguishable from females. Both sexes are brown to gray-brown dorsally and have light beards and dark faces. Eulemur fulvus has a disjunct distribution. According to Tattersall (1982), it occurs in $\geq 3$ distinct regions: in northwestern Madagascar, north of the Betsiboka River from south of Ambato-Boeni to Analalava; in the north, in a small area east of the Galoka Mountains, south of Beramanja; and in the east, south of Lac Alaotra and around Andasibe. Mittermeier et al. (1994) also suggested that the species may hybridize with Eulemur albifrons in some areas of eastern Madagascar. Evans et al. (1995) confirmed the presence of Eulemur fulvus in the Ambatovaky Special Reserve. Schmid (2000) reported Eulemur (fulvus) fulvus from the area between Mantadia and Zahamena, whereas Britt et al. (1999; Britt 2002) listed E. (f.) albifrons in the region of Betampona, south to Zahamena. Thus, the 2 taxa occur either sympatrically or parapatrically.

Eulemur sanfordi inhabits the northern part of Madagascar. The Mahavavy River is evidently the southwestern limit of its range, and the Manambato River the southeastern limit (Meyers and Ratsirarson 1989; Petter and Petter-Rousseaux 1979; Petter et al. 1977). In the northern part of its range, Eulemur sanfordi appears to be restricted to the immediate area of Montagne d'Ambre, Ankarana, and Analamerana, ranging south to Daraina (Tattersall 1982; E. E. Louis, unpubl. data). Throughout its range, Eulemur sanfordi appears to be sympatric with $E$. coronatus (Meyers and Ratsirarson 1989). The most notable characters of the species are light-colored ear tufts and beards, which together give the appearance 
of a mane, that is prominent in males. Female Eulemur sanfordi can be difficult to distinguish from female E. albifrons.

According to Tattersall (1982), Eulemur albifrons inhabits the humid forests of eastern Madagascar, with the southern limit of its range appearing to be near Tamatave along the coast and south of the Ivindro River (Goodman and Ganzhorn 2004), and to the north it reaches to the Fanambana River along the coast, near Vohémar, and extends as far west as the Marojejy Massif, north of Andapa. Eulemur albifrons have been caught at Marojejy, Anjanaharibe-Sud, Masoala, and Betampona, but they are also reported at Mananara-Nord; the population at Betampona is considered by some to have been introduced. However, others suggest a less northerly limit, only as far as the Bemarivo River, near Sambava, but perhaps a more westerly extension to the Tsaratanana Massif (Meyers and Ratsirarson 1989; Mittermeier et al. 1994). Perhaps connected with its relatively large range, there is considerable morphological variation in Eulemur albifrons. Tattersall (1982) mentioned 2 distinct color phases among males: one with a luxuriant white or cream-colored forehead and the other lacking the striking coloration. Female Eulemur albifrons do not possess the distinct white forehead and are difficult to distinguish from female E. fulvus or E. sanfordi based on coloration.

Eulemur rufus occurs in tropical dry lowland forest in the coastal regions of northwestern Madagascar, south from the Betsiboka River to the Tsiribihina River (Groves 2007). Until recently Eulemur rufifrons was considered to be a junior synonym of rufus (cf. Groves 2005; Mittermeier et al. 2006; Petter et al. 1977; Tattersall 1982), but both morphological and genetic evidence now argues clearly that rufifrons is distinct (Groves 2007; Pastorini et al. 2003). It occurs along the west coast south of the Tsiribihina River to the Fiheranana River, near Tuléar, including the Forêts de Mikea (Ganzhorn and Randriamanalina 2004) and has also been sighted south of the river in the forests of Lambomakandro. Eulemur rufifrons is the form covering the range formerly ascribed to E. rufus in eastern Madagascar (Groves 2007). There they occur as far north as the Mangoro River and the Onive River, as far to the southwest as Ivohibé at the southern end of the Andringitra Massif. Recent studies of Eulemur species by Sterling and Ramarason (1996), Johnson and Wyner (2000), and Wyner et al. (2002) provide evidence of hybridization zones between $E$. rufus (here considered to be rufifrons), E. collaris and E. cinereiceps (then called albocollaris) in the region. Other reports of hybridization among Eulemur spp. in the wild concern hybrids between E. macaco and E. (f.) fulvus (cf. Goodman and Schütz 2000; Schütz 2000) and even E. mongoz and E. fulvus (cf. Zaramody and Pastorini 2001). O'Connor (1987) also reported a small, introduced population of red-fronted lemurs at the Berenty Private Reserve in southern Madagascar that possibly hybridized there with introduced Eulemur collaris. Groves (1974), Albrecht et al. (1990), and Mittermeier et al. (1994) noted variation between eastern and western populations of the taxon in terms of both color and size. Groves (2001) identified 3 regional forms - eastern, southwestern and northwestern - but differences between the eastern and southwestern forms are relatively slight, and further studies showed that they are substantially the same (rufifrons), with the northwestern form being rufus as mentioned previously. In the mitochondrial DNA analysis of Pastorini et al. (2003), Eulemur rufifrons is part of a clade containing E. albifrons, E. sanfordi, and E. fulvus, to which E. rufus is a sister-group. 
Eulemur collaris occurs in southeastern Madagascar, where it ranges from the Mananara River near Vaingandrano south to Fort Dauphin, but the northern and western limits of its range are not well established (Tattersall 1982). Males are distinguished by a thick, elongated, cream to rufous beard; females also have a reddish beard, but it is significantly shorter than that of the males. Groves (2001) cited the unusually low $(2 n=50-52)$ and polymorphic chromosome number of this species (Buettner-Janusch and Hamilton 1979), and also the differences in fixed DNA sequences from other members of the genus demonstrated by Wyner et al. (1999).

There has been confusion about the taxonomic distinctness and naming of Eulemur cinereiceps, the resurrected priority name for the taxon intermittently described as E. albocollaris (cf. Johnson et al. 2008). Groves (2005) listed the little known, and evidently extremely rare, gray-headed lemur, Eulemur cinereiceps, first described as a variant of Lemur mongoz. The type locality is Farafangana, and it is known also from Solohy. Groves (2005) noted that the 2 known specimens in the Paris Museum are somewhat different and unlike any other known taxon. Groves (2001) discussed the specimens and compared their pelage color patterns with those of other Eulemur spp. The 19th century illustration and photographs of the 2 mounted specimens are in Mittermeier et al. (2006), along with a photograph of a captive animal taken by R. A. Mittermeier in Farafangana in 2005. Johnson et al. (2008) examined the validity or otherwise of Eulemur cinereiceps. Via field surveys and molecular genetic analyses, they (tentatively) concluded "that E. cinereiceps does not exist as a separate taxon from E. albocollaris" (p.384), which Rumpler (1975) described as Lemur fulvus albocollaris. Accordingly, Johnson et al. (2008) presented the case that albocollaris Rumpler, 1975 is a junior synonym. Eulemur cinereiceps has a very restricted range in southeastern Madagascar. Groves (2001) noted that the taxon has been set apart from other members of Eulemur fulvus based on its karyotype $(2 n=48$; Petter et al. 1977). It is also distinctly different from Eulemur collaris and E. fulvus with respect to molecular genetics (Wyner et al. 1999). The southern limit of its distribution is probably the Mananara River. Though Tattersall (1982) suggested that the Faraony River was the northern limit of its poorly surveyed range, Mittermeier et al. (1994) indicated that the species occurs only as far north as the Manampatrana River; much more conservative and $c a$. $150 \mathrm{~km}$ south of the Faraony. Recent studies by Sterling and Ramarason (1996), Johnson and Wyner (2000), Johnson (2002), and Wyner et al. (2002) provided evidence of Eulemur cinereiceps north of the Manampatrana River, as well as hybridization zones with E. collaris and E. rufus to the southeast of Andringitra National Park. Obviously rivers do not coincide with the distributional limits of the taxa (Goodman and Ganzhorn, 2004; Irwin et al. 2005). Even according to the preGroves taxonomy the 2 southern species of the Eulemur fulvus group (E. cinereiceps and E. collaris) seem genetically distinct enough from the other E. fulvus to warrant the status of distinct species (Djlelati et al. 1997; Wyner et al. 1999).

Tattersall (1982) indicated that the range of Eulemur mongoz has been more widely misquoted than that of any other lemur. It is native to northwestern Madagascar, but populations have been introduced to the islands of Mohéli and Anjouan in the Comores (Tattersall 1976b, 1977). On Madagascar, it occurs on both sides of the Betsiboka River, extending west to just south of Mitsinjo and north at 
least to the Bay of Narinda. The exact limits of its distribution remain poorly known because forests within its range are highly fragmented. Male Eulemur mongoz are gray-brown and darker than females, and also have a rufous beard that females lack. Though Groves (1974) and Petter et al. (1977) noted slight color differences between the Madagascar and Comores populations of the species, they may not be consistent and so would not warrant distinct taxonomic status.

Eulemur coronatus occurs in northern Madagascar. According to Tattersall (1982), it is the only lemur in the dry forests of the arid Cap d'Ambre. The southern limits of its range reach the Ankarana Massif in the west, between Ambilobé and Anivornao Nord, and the Fanambana River in the east, near Vohémar. Both sexes of Eulemur coronatus have a V-shaped marking pointed forward on the head, orange in females, black in most males, which gives the species the common name of crowned lemur.

Eulemur rubriventer inhabits forests of mid-altitude in eastern Madagascar, the Tsaratanana Massif, the northern limit of its range, and the southern end of the Andringitra Massif near Ivohibé which is the southern limit (Goodman and Ganzhorn 2004; Irwin et al. 2005; Jolly et al. 1984; Petter and Petter 1971; Tattersall 1982). Recent surveys failed to locate the species south of the Manampatrana River (Irwin et al. 2005), where it had been seen previously (Petter et al. 1977). It seems to occur at low densities throughout its range. The body pelage of Eulemur rubriventer is thick, long, and a rich dark chestnut brown. The ears are generally hidden by the fur. The face is dark and a patch of naked skin below each eye shows a pale teardrop pattern, which is particularly prominent in males. Geographic variation in the general pattern of coloration might indicate the existence of subspecies (Mittermeier et al. 1994).

\section{Varecia Gray, 1863: Ruffled lemurs}

Varecia variegata variegata (Kerr, 1792): Black-and-white ruffed lemur Varecia variegata editorum (Osman Hill, 1953): Southern ruffed lemur Varecia variegata subcincta (A. Smith, 1833): White-belted ruffed lemur

Varecia rubra (É. Geoffroy, 1812): Red ruffed lemur

Varecia includes the largest of the living quadrupedal lemurs. They are clearly recognized by their striking coloration, luxuriant pelage, long faces, and raucous, loud calls. They inhabit the rain forests of eastern Madagascar from the Mananara River, south of Farafangana, north to the Masoala Peninsula. Two distinct taxa have always been recognized, the black-and-red rubra from the Masoala Peninsula and the black-and-white variegata from the central portion of the eastern rain forests; until the early 1990s they were considered to be subspecies of the single species Varecia variegata. Researchers have noted, discussed, and named many color variants, especially for Varecia variegata (cf. Ceska et al. 1992; Petter et al. 1977; Mittermeier et al. 1994, 2006; Tattersall 1982, 1985), without resolution as to their taxonomic status. In particular, the validity of several subspecies proposed for Varecia variegata remains an open question, and has been hampered by the lack of information on geographic distribution and possible genetic differences between the forms. For example, Vasey and Tattersall (2002) examined variation in Varecia variegata in some detail, but concluded that the variants are not geographically exclusive, and therefore could not be considered subspecies. However, recent genetic 
studies by Louis et al. (2005) have indicated that 3 distinct evolutionarily significant units exist within variegata, and have reaffirmed the distinctiveness of Varecia rubra.

Groves (2001) recognized Varecia rubra and Varecia variegata as distinct species and resurrected 2 subspecies, $V$. v. editorum and $V$. v. subcincta, based on differences in pelage coloration that he felt corresponded to distinct geographic populations. His proposal seems in part to have been vindicated by the new genetic findings. We follow Groves and recognize 3 subspecies of Varecia variegata, with the following distributions along the Malagasy east coast. 1) Varecia v. subcincta is the northernmost of the $V$. variegata subspecies. Its range extends from the Antsaribe River (in the region of Maroantsetra) south to the Anove River (between Soanierana Ivongo and Mananara). 2) The Anove River (between Soanierana Ivongo and Mananara) is the northern limit of the known current range of Varecia variegata variegata. The southern limit is in the region of the Betampona Strict Nature Reserve and Zahamena National Park between Tamatave and Fenoarivo. 3) The known current range of Varecia variegata editorum extends from the forests of Mantadia National Park in the north to the Manombo Special Reserve in the south. We note that the type locality of the subspecies is given by Hill (1953) as "Ambatondrazaka, south of Lac Alaotra," which would be well north of the current known distribution and where today Varecia probably no longer occurs. However, researchers have not yet screened the remaining forests west of Tamatave, and it may well be that the subspecific range extends further north or that the ranges of Varecia variegata variegata and $V$. v. editorum overlap in the region.

Varecia rubra is largely red and black, with small patches of white on the neck, and sometimes on the heels, digits and muzzle. Most of the dorsal body coat is deep rusty red, whereas the ventrum, extremities, tail, inside of limbs, forehead, and crown (excluding ears) are black. As with Varecia variegata, variations in pattern exist (Ceska et al. 1992; Mittermeier et al. 1994, 2006). Varecia rubra is restricted to the forests of the Masoala Peninsula near Maroantsetra in northeastern Madagascar (Petter et al. 1977).

Further research on the taxonomy and distribution of Varecia variegata needs to be among the highest conservation priorities for Madagascar. The species is a preferred target for hunters throughout most of its range, and it seems to depend strongly on undisturbed mature primary rain forest. The range is now very patchy (Irwin et al. 2005), and all 3 taxa are ranked as Critically Endangered on the IUCN Red List (IUCN 2008). Further, we need to determine as soon as possible whether or not still more taxa exist.

\section{Family Indriidae Burnett, 1828}

According to Groves (2001), who cited Jenkins (1987), the original family name Indridae is correct, but Opinion 1995 of the International Commission on Zoological Nomenclature (2002) conserved and validated the prevalent spelling of Indriidae. Indriidae contains 3 subfamilies: Archaeolemurinae, Palaeopropithecinae, and Indriinae. The first 2 contain only extinct taxa, while the Indriinae contains 3 living genera: Avahi, Indri, and Propithecus. Avahi is the relatively small, nocturnal woolly 
lemur, while Indri and Propithecus are diurnal and much larger. All 3 genera are typical vertical clingers and leapers, preferring postures in which the trunk of the body is held vertically, and using their longer hind limbs and powerful thighs to make spectacular leaps between vertical supports.

\section{Avahi Jourdan, 1834: Avahi or Woolly lemur}

Avahi laniger (Gmelin, 1788): Eastern woolly lemur

Avahi occidentalis Lorenz, 1898: Western woolly lemur

Avahi unicolor Thalmann and Geissmann, 2000: Unicolor woolly lemur

Avahi cleesei Thalmann and Geissmann, 2005: Cleese's woolly lemur

Avahi peyrierasi Zaramody et al., 2006: Peyrieras' woolly lemur

Avahi meridionalis Zaramody et al., 2006: Southern woolly lemur

Avahi ramantsoavani Zaramody et al., 2006: Ramantsoavana's southern woolly lemur

Avahi betsileo Andriantompohavana et al., 2007: Betsileo woolly lemur

Avahi mooreorum Lei et al., 2008: The Moore's woolly lemur

Avahi contains the only nocturnal members of the family Indriidae. Avahis are small, with masses usually $\leq 1 \mathrm{~kg}$. Prominent white patches on the backs of the thighs contrast with the generally brown coloration and serve as distinguishing field marks. Until quite recently, the genus was considered to contain a single species, Avahi laniger, with 2 subspecies: the eastern $A$. l. laniger and the northwestern $A$. $l$. occidentalis (Tattersall 1982). However, Rumpler et al. (1990) elevated both to species, and Thalmann and Geissmann (2000, 2005) subsequently described a third, Avahi unicolor, from western Madagascar, and a fourth, A. cleesei, from the region of Bemaraha, distinguished from $A$. occidentalis by the lack of a white facial mask and broad dark eye rings, and from both $A$. occidentalis and A. laniger by a dark chevron pattern on the forehead (Thalmann and Geissmann 2005). According to Mittermeier et al. $(1994,2006)$ the distribution of Avahi occidentalis was discontinuous north of the Betsiboka River in western Madagascar. Thalmann and Geissmann (2000) agree with the southern limit and indicate that the species may extend as far north as the Mahajamba, Sofia, or Maevarano rivers around Ambondro-Ampasy.

The species of western avahi described by Thalmann and Geissmann (2000), $A$. unicolor, is probably restricted to the Sambirano region, including the Ampasindava Peninsula, with either the Andranomalaza or Maevarano rivers forming the southern boundary to its distribution, and the Sambirano River its northern limit. Raxworthy and Rakotondraparany (1988) report it from the western slope of the Manongarivo Special Reserve. The eastern limit to its range may be the western slope of the Tsaratanana Massif.

Cleese's avahi, Avahi cleesei, occurs only from the Tsingy de Bemaraha region, north of the Manambolo River. The northern limit to its range is unclear (Thalmann and Geissmann 2005). The eastern woolly lemur, Avahi laniger, occurs in eastern rain forest from the region of Fort Dauphin in the south to the Andapa region near Sambava in the north (Petter et al. 1977; Tattersall 1982). Fowler et al. (1989) and Hawkins et al. (1990) also reported it from the Ankarana Massif and west of Anivorano, in extreme northern Madagascar, respectively.

Cytogenetic and molecular genetic analyses (mitochondrial cytochrome $b$ ) by Zaramody et al. (2006) and Andriaholinirina (2006) revealed that the eastern woolly 
lemurs, formerly lumped as Avahi laniger, could be differentiated into $\geq 3$ so-called phylogeographic groups: 1) north of the Mangoro/Onive rivers, 2) south of the Mangoro/Onive rivers, and 3) from the southeast (Manombo and Saint Luce), which can in turn be separated into distinct clades. Though the exact type locality of Avahi laniger is unknown, Zaramody et al. (2006) determined that it must have been north of the Mangoro/Onive rivers. Therefore, they considered group 1 to be Avahi laniger. They named group 2 from the south of the Mangoro/Onive rivers as Avahi peyrierasi, type locality Mahasoarivo (Ranomafana ca. $47^{\circ} 26^{\prime} \mathrm{E}, 21^{\circ} 16^{\prime} \mathrm{S}$ ), Province of Fianarantsoa. It occurs in the forests of Manara, Vatoalatsaka, Sangalampona and Ranomafana. They also described group 3 as a new species, with 2 subspecies. Avahi m. meridionalis, type locality Sainte Luce (ca. $47^{\circ} 11^{\prime} \mathrm{E} ; 24^{\circ} 47^{\prime} \mathrm{S}$ ), Province of Toliara, is slightly smaller than A. laniger and A. peyrierasi, and occurs only from the Andohahela Reserve and the area of Sainte Luce. Avahi ramanantsoavani occurs at its type locality, Reserve of Manombo ( $c a .47^{\circ} 41^{\prime} \mathrm{E} ; 23^{\circ} 01^{\prime} \mathrm{S}$ ), Province of Fianarantsoa. Zaramody et al. (2006) considered Avahi ramanantsoavani to be a subspecies of Avahi meridionalis. However, we follow Andriantompohavana et al. (2007), who in their review of the molecular phylogeny of the genus, considered it to be a full species.

Andriantompohavana et al. (2007) described Avahi betsileo from Bemosary Classified Forest, District of Fandriana, Region Amoron'i Mania, Province of Fianarantsoa, Madagascar. Lei et al. (2008) described Avahi mooreorum, from the Masoala National Park, Province of Antsiranana (ca. 15 $40^{\prime} 008^{\prime \prime S}$; 49 $\left.9^{\circ} 7^{\prime} 476^{\prime \prime} \mathrm{E}\right)$.

Propithecus Bennett, 1832: Sifakas and Simponas

Propithecus diadema Group

Propithecus diadema Bennett, 1832: Diademed sifaka

Propithecus candidus Grandidier, 1871: Silky sifaka

Propithecus edwardsi Grandidier, 1871: Milne-Edward's sifaka

Propithecus perrieri Lavauden, 1931: Perrier's sifaka

Propithecus verreauxi Group

Propithecus verreauxi Grandidier, 1867: Verreaux's sifaka

Propithecus deckenii Peters, 1870: Decken's sifaka

Propithecus coronatus Milne-Edwards, 1871: Crowned sifaka

Propithecus coquereli (Grandidier, 1867): Coquerel's sifaka

Propithecus tattersalli Simons, 1988: Tattersall's sifaka; golden-crowned sifaka

All the sifakas are diurnal, large and long-tailed, and have very long hind limbs relative to the trunk and forelimbs. They move by leaping between vertical supports, propelled by their powerful hind limbs. On the ground they bound along on their hind limbs in an upright position. Until the late 1980s, only 2 species of Propithecus were recognized, $P$. diadema and $P$. verreauxi, the former with 5 subspecies and the latter with 4 (Tattersall 1982). Simons (1988) described a third species, Propithecus tattersalli, after Ian Tattersall, who had discovered a population in northern Madagascar near Daraina in 1974 and had provisionally ascribed it to Propithecus diadema candidus. In the center of their ranges the currently recognized taxa of Propithecus are each physically distinctive. Yet, the combination of morphological, cytogenetic, and molecular genetic data yield ambiguous results that allow different classifications of the different taxa. 
Groves (2001) suggested that the taxonomic arrangement of only 3 species was ill-advised and merely a legacy of Schwarz's (1931) tendency to lump. Schwarz (1931) placed 9 forms, including holomelas Günther, 1875 and majori Rothschild, 1894 as subspecies of $P$. diadema or $P$. verreauxi. Lavauden described Propithecus perrieri only in 1931, but Hill (1953), following Schwarz's lumping tendency, placed it as a subspecies of P. diadema (cf. Groves and Helgen 2007). Groves (2001) as such listed Propithecus edwardsi, P. perrieri, P. coquereli, and P. deckenii as full species, and divided the genus into 2 species groups: the Propithecus diadema group (P. edwardsi, P. perrieri, P. tattersalli, and P. diadema with 2 subspecies, $P$. $d$. diadema and $P$. d. candidus) and the $P$. verreauxi group ( $P$. verreauxi, $P$. coquereli, and $P$. deckenii with 2 subspecies, $P$. d. deckenii and $P$. d. coronatus). Groves (2005) listed them all as species, except for candidus (a subspecies of Propithecus diadema) and coronatus (a subspecies of $P$. deckenii). The taxonomy we adopt here, regarding all as species, is that proposed by Groves and Helgen (2007).

Cytogenetic studies have confirmed the specific status of Propithecus edwardsi, with $2 n=44$ chromosomes separating it from $P$. diadema, $P$. perrieri, and $P$. candidus, all with $2 n=42$ chromosomes (Mayor et al. 2004; Rumpler and Albignac 1979; Rumpler et al. 1988, 2004). Molecular genetic studies of Mayor et al. (2004) have also confirmed the distinction. However, cytogenetic studies do not separate $P$. diadema, P. candidus, and P. perrieri (Mayor et al. 2004; Rumpler et al. 2004). Conversely, D-loop sequences and microsatellite analyses combine Propithecus perrieri and P. candidus, but separate out P. diadema (Mayor et al. 2004). A discriminant function based on morphological data of the same species (Mayor et al. 2004) matched neither the clustering of the genetic analyses nor the clusters proposed by Groves (2001). Cytogenetics and molecular genetics as such give us no clear picture.

However, Groves and Helgen (2007) noted that Propithecus perrieri was originally described as a full species, and that its placement as a subspecies of Propithecus diadema by Hill (1953) was nothing more than a question of convenience; Groves (2001, 2005) listed it as a species. Groves (2001) maintained candidus as a subspecies of Propithecus diadema because of the report by Petter et al. (1977) that pelage variation in candidus approached diadema. Later Groves and Helgen (2007) listed candidus as a separate species, referring to the results of a comparative study of male throat gland histology by Rumpler and Andriamiandra (1971) and to comparative craniometry. Agreeing with Groves and Helgen (2007), we recognize the 3 distinct and geographically isolated sifakas as species: Propithecus diadema, $P$. candidus, and P. perrieri, along with $P$. edwardsi.

Researchers have debated the taxonomic status of Propithecus tattersalli. Groves (2001) assigned it to the Propithecus diadema group, supported by microsatellite analyses that link $P$. tattersalli with $P$. edwardsi (cf. Mayor et al. 2004). In contrast, the study of mtDNA by Pastorini et al. (2001a, 2003) grouped Propithecus tattersalli with the $P$. verreauxi group, and even, assuming a version of the Genetic Species Concept, called into question whether or not it deserved specific status. Independent analyses of mitochondrial DNA (Mayor et al. 2004; Pastorini et al. 2001a) and clusters based on morphological characteristics (Mayor et al. 2004) have confirmed the close link between Propithecus tattersalli and P. coquereli. The karyotype separates it from all other forms of Propithecus (Mayor et al. 2004; Rumpler et al. 
2004). Accordingly, we recognize Propithecus tattersalli as a distinct species, and believe that it is best placed with the $P$. verreauxi group.

Within the Propithecus verreauxi group the genetic evidence supports Groves and Helgen's (2007) morphological analysis concerning P. coquereli, separating it as a distinct taxon that can be considered a species (Mayor et al. 2004: Y. Rumpler, pers. comm.). Though they maintained them as subspecies, Petter et al. (1977) reported on skull differences that clearly separated Propithecus coronatus and P. deckenii from other members of the $P$. verrauxi group. Groves $(2001,2005)$ maintained coronatus as a subspecies of Propithecus deckenii on the basis of the reports of Tattersall (1986) that deckenii-like and coronatus-like sifakas could be seen in the same areas, and on the observations concerning their geographic ranges by Thalmann and Rakotoarison (1994). Tattersall (in Simons 1988) even thought they might be synonyms. Curtis et al. (1998) surveyed the lower Mahavavy du Sud River and were unable to confirm overlap in their ranges, with Propithecus deckenii occurring to the west and $P$. coronatus to the east. In a review of the ranges of the 2 forms, Thalmann et al. (2002) concluded that they are distinct species according to the Phylogenetic Species Concept, if not under the Biological Species Concept, and Groves and Helgen (2007) also found a clear separation of the 2 in their skull morphology. With Propithecus tattersalli, $P$. coronatus has the most distinctive cranium of any of the members of the Propithecus verreauxi group.

In contrast to the morphological evidence, molecular data support neither the distinction of Propithecus deckenii from P. verreauxi nor the distinction of the 2 subspecies within P. deckenii (cf. Pastorini et al. 2003; Y. Rumpler, pers. comm.). Although providing no new data on Propithecus deckenii or P. coronatus, Mayor et al. (2004) list them both as subspecies of Propithecus verreauxi, an arrangement also preferred by Yves Rumpler, whose genetic analyses confirm most of the conclusions of Mayor et al. (2004) and have been unable, like Pastorini et al. (2003), to distinguish deckenii, verreauxi, and coronatus. We fully acknowledge the reservations of Mireya Mayor and Yves Rumpler, but we here follow the morphological and biogeographic arguments of Mittermeier et al. (2006) and Groves and Helgen (2007) in concluding that all the currently recognized members of the genus are diagnosably distinct species.

Propithecus diadema is the largest and most colorful member of Propithecus. Researchers have reported adult masses of 6-7 kg, which are similar to those of Indri (cf. Powzyk and Mowry 2003). The pelage is largely white, with black on the head, back of the neck and the hands and feet, and gold at the base of the tail, on the hindquarters and the limbs. It was one of the most widespread of the sifakas; its distribution in the eastern rain forests extended from the Mangoro River north to somewhere below the Antainambalana River, south of Maroantsetra (Mittermeier et al. 1994, 2006). However, it now appears to be absent from many areas where it was not difficult to find just a few years ago (K. Glander, pers. obs.). Mittermeier et al. (2006, illustrated p. 379) reported on a variable but distinctive form from Tsinjoarivo, south-central Madagascar. M. Irwin and K. Glander showed that the Tsinjoarivo sifakas were very variable in appearance (Mittermeier et al. 2006), and significantly smaller (average $4963 \mathrm{~g}, \mathrm{SD} \pm 523 \mathrm{~g}, \mathrm{n}=12$ ) than either Propithecus edwardsi or $P$. diadema (unpubl. data), and also indicated differences in vocalizations (K. Glander, in litt. January 31, 2007). However, cytogenetic studies from an individual captured 
at Tsinjoarivo by K. Glander, analyzed at the Center for Reproduction of Endangered Species (CRES), San Diego Zoo (Mayor et al. 2004), mtDNA evidence (data from 12 individuals; E. E. Louis and M. I. Mayor, unpubl. data), and morphological data (from the same 12 individuals; W. Jungers and M. I. Mayor, unpubl. data), otherwise failed to provide a case for distinguishing them from Propithecus diadema (M. I. Mayor, in litt. January 26, 2007). Andriaholinirina (2006), likewise, was unable to find evidence from cytogenetic studies and mitochondrial sequencing that could support the argument that the Tsinjoarivo population was distinct, despite their smaller size and clear differences in the appearances of forms from 4 different areas within the currently recognized range of Propitheus diadema (cf. Mittermeier et al. 2006): 1) Mantadia/Maromizaha show typical color of $P$. diadema (yellow-gold limbs, slate gray to silvery gray back, light-gray and white face and light gray crown); 2) Andilamena (the forests of Antsahaporetiny, Behorefo, and Ivongo) with a much lighter yellow body, almost white, the gray parts also much lighter, and the nape is slightly darker, almost black, and with white around the face; 3) Zahamena with a dark gray, almost black face and black back; and 4) Anosiben'Ifody, Vatateza, and Ambohimanjaka typically have a black head, with a white band above the eyes, and a very black back (Andriaholinirina 2006; in litt. February 12, 2007).

The range of Propithecus candidus, a distinctive species covered entirely in long white hair, is restricted to northern Madagascar in a humid forest belt that runs from Maroantsetra to the Andapa Basin and the Marojejy Massif. The Androranga River may be the northwestern range limit within the Tsaratanana Corridor. The Antainambalana River, within the Makira Conservation Site, is currently regarded as the southern limit (Patel and Andrianandrasana 2008; Rasolofoson et al. 2007; Tattersall 1982; Wilmé and Callmander 2006).

Propithecus edwardsi, in contrast to P. candidus, is almost entirely black or dark chocolate brown, save for white flank patches that sometimes meet across the back. Its range in eastern Madagascar lies south of that of Propithecus diadema, the Mangoro/Onive River forming its present northern limit and the Mananara River its southern boundary (Andriaholinirina et al. 2004; Tattersall 1982), though no recent survey has confirmed this species south of the Manampatrana River, much farther north than the Mananara River (Irwin et al. 2005). Tattersall (1986) suggested that it might have occurred north of the Mangoro in the past, and former inland populations of the species have apparently been extirpated (Mittermeier et al. 1994).

A few authors have recognized the subspecies Propithecus diadema holomelas, a black form with all black under parts and a dark brown patch at the base of the tail. It was reported during the late 1800s and only from the forests of Nandihizana, $c a$. $50 \mathrm{~km}$ north of Fianarantsoa. Groves (2001) noted that it lacks the white flank patches typical of Propithecus edwardsi. Petter et al. (1977) argued that it was a melanistic morph of edwardsi, though Albrecht et al. (1990) found that its skull length was notably smaller (Groves 2001; Groves and Helgen 2007). The molecular data of Andriaholinirina (2006) confirmed the previous results of Petter et al. (1977). Tattersall (1986) reported that holomelas-like and edwardsi-like forms were syntopic, and both Tattersall (1986) and Groves (2001, 2005) considered holomelas to be a synonym of Propithecus edwardsi, but Groves and Helgen (2007) kept specimens of holomelas from Andalusa and Fienerentova separate in their analysis of the cranial morphology of the genus, and confirmed the findings of Albrecht 
(1990). Groves and Helgen (2007) indicated that it could in fact be a good species, but further research is needed. Unfortunately, it appears that no Propithecus survive today in the forests where researchers recorded holomelas. Further surveys are required.

Propithecus perrieri is somewhat similar in coloration to P. edwardsi, but its long and silky, shiny, fur is typically black on the back and brownish on the chest and belly. It occurs far to the north in Madagascar in extremely dry forests northeast of the Andrafiamena Mountains and east of Anivorano Nord (Mayor and Lehman 1999; Meyers and Ratsirarson 1989; Petter et al. 1977; Ranaivoarisoa et al. 2006; Tattersall 1982).

Propithecus tattersalli is a small- to medium-sized sifaka, weighing only about half as much as $P$. diadema. It is mostly white, but with distinctive protruding ears, a cap of golden fur on the head, and gold coloration on the shoulders (Mittermeier et al. 1994, 2006). The species has a very restricted distribution, occurring in both deciduous and semi-evergreen forest between the Loky and Manambato rivers, its range centered on the northern Madagascar town of Daraina (Meyers and Ratsirarson 1989; Randrianarisoa et al. 1999; Tattersall 1982; Vargas et al. 2002).

Propithecus coquereli differs from $P$. verreauxi in having extensive marooncolored patches on the chest, the front of the thighs, and the forelimbs. Otherwise it is also a small- to medium-sized white sifaka. Its distribution includes dry deciduous forested areas of northwestern Madagascar to the north and east of the Betsiboka River. The region of Ambato-Boéni appears to represent its southeastern extent, while the northern limit of its range seems to run from Antsohihy to Befandriana (Tattersall 1982).

Propithecus verreauxi is another small, predominantly white, sifaka. The top of its head is black or chocolate brown. It has the largest range of any member of the genus. Populations occur in southern and southwestern Madagascar, extending from just west of Fort Dauphin in the south to the Tsiribihina River, along the western coast in the central part of the country (Mittermeier et al. 1994). Propithecus verreauxi majori Rothschild, 1894 exists in the literature, but is now considered nothing more than a color variant (Groves 2001, 2005; Mittermeier et al. 1994, 2006).

Propithecus deckenii is restricted to the region between the Manambolo and Mahavavy rivers in coastal western Madagascar (Thalmann et al. 1999, 2002). The distribution of Propithecus coronatus forms a crescent around P. deckenii, extending along the coast south of the Manambolo River, inland to elevations of 500-1000 m, and then back to the coast north and east of the Mahavavy River (Thalmann et al. 1999, 2002). The pelage of Propithecus coronatus is yellowish to silvery-brown dorsally, dark on the chest, and chocolate brown to black on the crown, forehead, cheeks, and throat. It has a bulbous nose that distinguishes it from other sifakas.

\section{Indri É. Geoffroy and G. Cuvier, 1796: Indri}

Indri indri (Gmelin, 1788): Indri

There is only a single species of Indri, which is the largest of the living lemurs, with an adult body mass averaging $6-7 \mathrm{~kg}$ (reaching $\leq 9 \mathrm{~kg}$ ) and a head-body length of $\geq 60 \mathrm{~cm}$. In addition to their large size, diurnal Indri indri are distinguished from all other lemurs by having vestigial tails. Though the extent and pattern of the black- 
and-white coloration may vary, the ears are always black, tufted and prominent. Indri resides in Madagascar's eastern humid forests, ranging from the Mangoro River in the central-eastern part of the country north to near Sambava, but excluding the Masoala Peninsula (Mittermeier et al. 1994, 2006; Petter et al. 1977; Tattersall 1982).

Northern specimens tended to be darker than southern specimens, and Thalmann et al. (1993) reported a mixed pattern in the region of Mananara, and Groves (2001, 2005) recognized 2 subspecies, Indri indri indri and I. $i$. variegatus, on the basis of this study. Indri indri indri from the northern part of the species' distribution, and typical of specimens reported from Anjanaharibe-Sud (Thalmann et al. 1993) and Ambatovaky (Evans et al. 1995), are almost entirely black. They lack a light occipital patch and light tones on the outer forelimbs and hind limbs, but have a broad face ring. Groves (2001) considered museum specimens from Andapa and Maroantsetra to be this subspecies as well. Groves (2001) suggested that the lightercolored form, which he listed as Indri indri variegatus (Gray, 1872), occurs southward from the region of Mananara. It has a white occipital patch, a white collar extending up to and behind the ears, and the outside of its forelimbs and hind limbs are grayish or whitish, and is the variant in the Analamazaotra Special Reserve at Andasibé (=Perinet). Differentiation between the 2 is not supported by genetic or new morphological evidence (Zaonarivelo et al. 2007).

\section{Family Daubentoniidae Gray, 1863}

The Daubentoniidae has only 1 living species, Daubentonia madagascariensis, the aye-aye. It is separated from all the other lemurs by its highly specialized dentition, including ever-growing incisors, a unique feature among primates; exceptionally large ears; and an elongated middle digit on both hands. The ears and elongated digits are used in the detection and consumption of insect larvae in dead wood (Mittermeier et al. 1994, 2006). Schwarz and Tattersall (1985) contended that the aye-aye's closest affinities are with the indriids. A reconstruction of the ancestral karyotype of the lemurs by Warter et al. (2005), and the wide-ranging genetic studies of Yoder et al. (1996) and DelPero et al. (2006) indicate that Daubentonia separated long before any other branch of the Lemuriformes.

Remains of a second, much larger, extinct species, Daubentonia robusta, occur at a few sites in Madagascar, and it appears that it was the last lemur species to go extinct, having possibly still existed until the 19th century.

\section{Daubentonia É. Geoffroy, 1795: Aye-aye}

Daubentonia madagascariensis (Gmelin, 1788): Aye-aye

Daubentonia madagascariensis is a medium-sized lemur, with a head-body length of $c a .40 \mathrm{~cm}$, a slightly longer tail, and a mass of $c a .3 \mathrm{~kg}$. It is covered in long, coarse, white-tipped black fur, and has the most prominent ears of any lemur. In the 1960s, the species was thought to be on the verge of extinction and down to just a handful of individuals. But in the past 2 decades, survey work has indicated that the aye-aye has in fact the most extensive distribution of any lemur species, and is widespread in both humid and dry forest habitats. It is very sparsely distributed 
and occurs only at low densities but, contrary to beliefs as recently as the early 1980s, it is far from being close to extinction (Goodman and Schütz 1999, 2000; Randrianarisoa et al. 1999; Simons 1993; Simons and Meyers 2001; Sterling 1998; Thalmann et al. 1999). It is possible, even probable, that aye-ayes in different parts of Madagascar could be distinct from each other; unfortunately, there are very few museum specimens outside of Madagascar, so a morphological study is impossible at present. It is essential that field workers should collect dead specimens, and genetic studies around Madagascar should be conducted.

Acknowledgments We thank Douglas Brandon-Jones for his expert advice on a number of aspects of the taxonomy of the lemurs. We also thank the Disney Institute, Orlando, Florida, and especially Kim Sams, Rick Barongi, and Anne Savage, for hosting the original IUCN/SSC Primate Specialist Group workshop "Primate Taxonomy for the New Millennium," February 25-29, 2000. Numerous people most kindly provided excellent suggestions, advice and insights, and unpublished information during postworkshop discussions concerning particular genera, especially Nicole Andriaholinirina, Rick Brenneman, Frank Hawkins, Mitchell Irwin, Steig Johnson, William Jungers, Olivier Langrand, and Stephen Nash.

\section{References}

Affolter, M. (1938). Les organes cutanés brachiaux mâles d'Hapalemur griseus. Bulletin de l'Académie Malgache, 20, 77-100.

Albrecht, G., Jenkins, P. D., \& Godfrey, L. R. (1990). Ecogeographic size variation among the living and subfossil prosimians of Madagascar. American Journal of Primatology, 22, 1-50. doi:10.1002/ ajp.1350220102.

Andriaholinirina, N. (2006). Contribution à la révision systématique de deux genres d'Indriidae (Avahi, Jordan 1834 et Propithecus, Bennett 1832) de la côte Est de Madagascar. Thèse de Doctorat en Sciences, Spécialité: Primatologie, Dépt. d'Anthropologie, Antananarivo, 30 novembre, Madagascar.

Andriaholinirina, N., Rabarivola, C., \& Rumpler, Y. (2004). Limites de la zone de répartition de Propithecus diadema diadema et Propithecus diadema edwardsi. Lemur News, 9, 18-19.

Andriaholinirina, N., Rabarivola, C., \& Rumpler, Y. (2005). Cytogenetic study of Lepilemur microdon. Folia Primatologica, 76, 238-241. doi:10.1159/000086027.

Andriaholinirina, N., Fausser, J.-L., Roos, C., Ravaoarimanana, I., Zinner, D., et al. (2006a). Molecular phylogeny and taxonomic revision of the sportive lemurs (Lepilemur, Primates). BMC Evolutionary Biology, 6, 17. doi:10.1186/1471-2148-6-17.

Andriaholinirina, N., Rabarivola, C., Zaramody, A., Roos, C., Zinner, D., Fausser, J.-L., et al. (2006b). Cytogenetic and molecular characterization of the newly described sportive lemur Lepilemur jamesi (Louis et al. 2006). Primate Report, 74, 25-33.

Andriamiandra, A., \& Rumpler, Y. (1968). Rôle de la testostérone sur le déterminisme des glandes brachiales et antébrachiales chez le Lemur catta. Comptes Rendus des Seances de la Société de Biologie et de ses Filiales, 16, 1651-1655.

Andrianjakarivelo, V. (2004). Exploration de la zone en dehors de la peninsule Sahamalaza pour l'évaluation rapide de la population d'E. m. flavifrons. Report, Wildife Conservation Society (WCS) Madagascar, Antananarivo, 31pp.

Andriantompohavana, R., Zaonarivelo, J. R., Engberg, S. E., Randriamampionona, R., McGuire, S. M., Shore, G. D., et al. (2006). Mouse lemurs of northwestern Madagascar with a description of a new species at Lokobe Special Reserve. Occasional Papers of the Museum of Texas Tech University, 259, 1-24.

Andriantompohavana, R., Lei, R., Zaonarivelo, J. R., Engberg, S. E., Nalanirina, G., McGuire, S. M., et al. (2007). Molecular phylogeny and taxonomic revision of the woolly lemurs, genus Avahi (Primates: Lemuriformes). Museum of Texas Tech University. Special Publication, 51, 1-59.

Anonymous. (1900). Voyage du Général Gallieni (Cinq Mois autour de Madagascar). Le Tour du Monde. Journal des Voyages et des Voyageurs Paris, Hachette, Nouvelle Série, 6e Année, Vol. 11, 182 pp.

Atsalis, S., Schmid, J., \& Kappeler, P. M. (1996). Metrical comparison of three species of mouse lemur. Journal of Human Evolution, 31, 61-68. doi:10.1006/jhev.1996.0049. 
Bachmann, L., Rumpler, Y., Ganzhorn, J. U., \& Tomiuk, J. (2000). Genetic differentiation among natural populations of Lepilemur ruficaudatus. International Journal of Primatology, 21, 853-864. doi:10.1023/A:1005546709911.

Baker, R. J., \& Bradley, R. D. (2006). Speciation in mammals and the Genetic Species Concept. Journal of Mammalogy, 87, 643-662. doi:10.1644/06-MAMM-F-038R2.1.

Bradley, R. D., \& Baker, R. J. (2001). A test of the Genetic Species Concept: Cytochrome- $b$ sequences and mammals. Journal of Mammalogy, 82, 960-973. doi:10.1644/1545-1542(2001)082<0960: ATOTGS $>2.0 . \mathrm{CO} ; 2$.

Brandon-Jones, D., Eudey, A. A., Geissmann, T., Groves, C. P., Melnick, D. J., Morales, J. C., et al. (2004). Asian primate classification. International Journal of Primatology, 25, 97-164. doi:10.1023/ B:IJOP.0000014647.18720.32.

Britt, A. (2002). The current status of lemurs in the Sahivo and Antanamalaza classified forests, and the forest of Ambakaka, Toamasina. Lemur News, 7, 19-20.

Britt, A., Axel, A., \& Young, R. (1999). Brief surveys of two classified forests in Toamasina Province, eastern Madagascar. Lemur News, 4, 25-28.

Buettner-Janusch, J., \& Hamilton, A. (1979). Chromosomes of Lemuriformes. IV. Karyotype evolution in Lemur fulvus collaris (É. Geoffroy, 1812). American Journal of Physical Anthropology, 50, 363-365. doi:10.1002/ajpa.1330500310.

Ceska, V., Hoffman, H.-U., \& Winkelsträter, K.-H. (1992). Lemuren im zoo. Berlin: Verlag Paul Parey.

Clark, A. (2002). What is a DPS vs. an ESU? Conservation Biology in Practice Winter 2002: 13.

Cracraft, J. (1983). Species concepts and speciation analysis. In R. F. Johnston (Ed.), Current ornithology, vol. 1 (pp. 159-187). New York: Plenum Press.

Craul, M., Zimmermann, E., Rasoloharijaona, S., Randrianambinina, B., \& Radespiel, U. (2007). Unexpected species diversity of Malagasy primates (Lepilemur spp.) in the same biogeographical zone: A morphological and molecular approach with the description of two new species. $B M C$ Evolutionary Biology, 7, 83. doi:10.1186/1471-2148-7-83.

Curtis, D. J., Velo, A., Raheliarisoa, E. O., Zaramody, A., \& Mueller, P. (1998). Surveys on Propithecus verreauxi deckeni, a melanistic variant, and P. v. coronatus in north-west Madagascar. Oryx, 32, 157164. doi:10.1046/j.1365-3008.1998.d01-25.x.

DelPero, M., Pozzi, L., \& Masters, J. C. (2006). A composite molecular phylogeny of living lemuroid primates. Folia Primatologica, 77, 434-445. doi:10.1159/000095390.

DeWeerdt, S. (2002). What really is an evolutionary significant unit? Conservation Biology in Practice, 3 , 10-17. doi:10.1111/j.1526-4629.2002.tb00022.x.

Djlelati, R., Brun, B., \& Rumpler, Y. (1997). Meiotic study of hybrids in the genus Eulemur and taxonomic considerations. American Journal of Primatology, 42, 235-245. doi:10.1002/(SICI)10982345(1997)42:3<235::AID-AJP6>3.0.CO;2-Y.

Dolch, R., Hilgartner, R. D., Ndriamiary, J.-N., \& Randriamahazo, H. (2004). "The grandmother of all bamboo lemurs": Evidence for the occurrence of Hapalemur simus in fragmented rainforest surrounding the Torotorofotsy marshes, Central Eastern Madagascar. Lemur News, 9, 24-26.

Dolch, R., Fiely, J. L., Ndriamiary, J.-N., Rafalimandimby, J., Randriamampionona, R., Engberg, S. E., et al. (2008). Confirmation of the greater bamboo lemur, Prolemur simus, north of the Torotorofotsy wetlands, eastern Madagascar. Lemur News, 13, 14-17.

Elliot, D. G. (1913). A review of the primates, 3 vols. New York: American Museum of Natural History.

Evans, M. I., Thompson, P. M., \& Wilson, A. (1995). A survey of the lemurs of Ambatovaky Special Reserve, Madagascar. Primate Conservation, 14-15, 13-21.

Fausser, J.-L., Prosper, P., Donati, G., Ramanamanjato, J.-B., \& Rumpler, Y. (2002). Phylogenetic relationships between Hapalemur species and subspecies based on mitochondrial DNA sequences. BMC Evolutionary Biology 2:4. Web site: http://www.biomedcentral.com/1471-2148/2/4).

Forsyth Major, C. I. (1894). Ueber die Malagassischen Lemuriden-Gattungen Microcebus, Opolemur, und Chirogale. Novitates Zoologicae, 1, 2-39.

Forsyth Major, C. I. (1896). Diagnoses of new mammals from Madagascar. Annals and Magazine of Natural History, 18, 318-325.

Fowler, S. V., Chapman, P., Checkley, D., Hurd, S., McHale, M., Ramangason, G.-S., et al. (1989). Survey and management proposals for a tropical deciduous forest reserve at Ankarana in northern Madagascar. Biological Conservation, 47, 297-313. doi:10.1016/0006-3207(89)90072-4.

F.T.M. (1990). Carte de Madagasikara 1:500,000 No 8, Antananarivo. Antananarivo: FoibenTaosarintanin'i Madagasikara (FTM).

Ganzhorn, J. U., \& Randriamanalina, M. H. (2004). Les lémuriens de la forêt de Mikea. In A. P. Raselimanana, \& S. M. Goodman (Eds.), Inventaire floristique et faunistique de la forêt de Mikea: 
Paysage écologique et diversité biologique d'une préoccupation majeure pour la conservation. Vol. 21 (pp. 87-93). Antananarivo: Ministère de l'Education Nationale et de la Recherche Scientifique.

Ganzhorn, J. U., Goodman, S. M., Nash, S., \& Thalmann, U. (2006). Lemur biogeography. In S. M. Lehman, \& J. G. Fleagle (Eds.), Primate biogeography: Progress and prospects (pp. 229-254). Cambridge: Cambridge University Press.

Garbutt, N. (2000). Brief observations of hairy-eared dwarf lemur (Allocebus trichotis) in Analamazaotra Special Reserve, eastern Madagascar. Lemur News, 6, 37.

Geoffroy St. Hilaire, É. (1812). Notes sur trios dessins de Commerçon. Annales Muséum National D'Histoire Naturelle, Paris, 19, 171-175.

Geoffroy St. Hilaire, É. (1828). Cours de l'Histoire Naturelles des Mammiferes. Paris.

Godfrey, L., \& Vuillaume-Randriamananatena, M. (1986). Hapalemur simus: Endangered lemur once widespread. Primate Conservation, 7, 92-96.

Godfrey, L. R., Simons, E. L., Jungers, W. L., DeBlieux, D. D., \& Chatrath, P. S. (2004). New discovery of subfossil Hapalemur simus, the greater bamboo lemur, in western Madagascar. Lemur News, 9, 9-11.

Goodman, S. M., \& Ganzhorn, J. U. (2004). Biogeography of lemurs in the humid forests of Madagascar: The role of elevational distribution and rivers. Journal of Biogeography, 31, 47-55. doi:10.1111/ j.1365-2699.2004.00953.x.

Goodman, S. M., \& Langrand, O. (1996). A high mountain population of the ring-tailed lemur Lemur catta on the Andringitra Massif, Madagascar. Oryx, 30, 259-268.

Goodman, S. M., \& Raselimanana, A. P. (2002). The occurrence of Allocebus trichotis in the Parc National de Marojejy. Lemur News, 7, 21-22.

Goodman, S. M., \& Raselimanana, A. (2003). Hunting of wild animals by Sakalava of the Menabe region: A field report from Kirindy-Mite. Lemur News, 8, 4-6.

Goodman, S. M., \& Schütz, H. (1999). Observations of lemurs in the forest east of Tsinjoarivo, Ambatolampy. Lemur News, 4, 14-16.

Goodman, S. M., \& Schütz, H. (2000). The lemurs of the northeastern slopes of the Réserve Spéciale de Manongarivo. Lemur News, 5, 30-33.

Goodman, S. M., \& Soarimalala, V. (2002). Les petits mammifères de la Réserve Spéciale de Manongarivo, Madagascar. Boissiera, 59, 384-401.

Goodman, S. M., Razafindratsita, V. R., Schütz, H., \& Ratsimbazafy, R. (2001). Les lémuriens. In S. M. Goodman, \& V. R. Razafindratsita (Eds.), Inventaire biologique du Parc National de Ranomafana et du couloir forestier qui la relie au Parc National d'Andringitra, Vol. 17 (pp. 231-243). Antananarivo: Centre d'Information et de Documentation Scientifique et Technique.

Goodman, S. M., Raherilalao, M. J., Rakotomalala, D., Rakotondravony, D., Raselimanana, A. P., Razakarivony, H. V., et al. (2002). Inventaire des vertébrés du Parc National de Tsimanampetsotsa (Toliara). Akon'ny Ala, 28, 1-36.

Goodman, S. M., Ganzhorn, J. U., \& Rakotondravony, D. (2003). Introduction to the mammals. In S. M. Goodman, \& J. P. Benstead (Eds.), The natural history of Madagascar (pp. 1159-1186). Chicago: The University of Chicago Press.

Grandidier, A. (1867). Description d'une nouvelle espece de Chirogale. Annales des Sciences Naturelles 5th series Zoologie Paléontologie, 8, 294.

Grandidier, A. (1868). Sur les découverts zoologique daite récemment a Madagascar. Annales des Sciences Naturelles 5th series Zoologie Paléontologie, 10, 375-378.

Grandidier, A. (1870). Description de quelques animaux nouveaux découverts a Madagascar en novembre 1869. Revue et Magasin de Zoologie Pure et Appliquée, 22(2), 49-50.

Gray, J. E. (1870). Catalogue of monkeys, lemurs, and fruit-eating bats in the collection of the British museum. London: British Museum Trustees.

Gray, J. E. (1872). Notes on Propithecus, Indris and other lemurs (Lemurina) in the British Museum. Proceedings of the Zoological Society of London, 1872, 846-860.

Groeneveld, L. F. (2008). Species Delimitation, Phylogeography and Population Genetics of the Endemic Malagasy Dwarf Lemurs (Genus Cheirogaleus). Doctoral thesis, University of Göttingen, Göttingen.

Groeneveld, L. F., Rasoloarison, R. M., Roos. C., \& Kappeler, P. M. (2005). Genetic diversity of the endemic Malagasy genus Cheirogaleus. Primate Report Special Issue 72-1:30. Abstract. 5 Göttinger Freilandtage Primate Diversity-Past, Present and Future, Deutsches Primatenzentrum, Göttingen, December 13-16, 2005.

Groves, C. P. (1974). Taxonomy and phylogeny of prosimians. In R. D. Martin, G. A. Doyle, \& A. C. Walker (Eds.), Prosimian biology (pp. 449-473). London: Duckworth.

Groves, C. P. (2000). The genus Cheirogaleus: Unrecognized biodiversity in dwarf lemurs. International Journal of Primatology, 21, 943-962. doi:10.1023/A:1005559012637. 
Groves, C. P. (2001). Primate taxonomy. Washington, DC: Smithsonian Institution Press.

Groves, C. P. (2004). The what, why and how of primate taxonomy. International Journal of Primatology, 25, 1105-1126. doi:10.1023/B:IJOP.0000043354.36778.55.

Groves, C. P. (2005). Order primates. In D. E. Wilson, \& D. M. Reeder (Eds.), Mammal species of the world: A taxonomic and geographic reference, Vol. 1 (pp. 111-184, 3rd ed.). Baltimore: Johns Hopkins University Press.

Groves, C. P. (2007). Red-fronted lemurs are not the same as red lemurs. Australasian Primatology, 18(1), 23 Abstract.

Groves, C. P., \& Eaglen, R. H. (1988). Systematics of the Lemuridae (Primates, Strepsirhini). Journal of Human Evolution, 17, 513-538. doi:10.1016/0047-2484(88)90040-1.

Groves, C. P., \& Helgen, K. M. (2007). Craniodental characters in the taxonomy of the sifakas (Propithecus). International Journal of Primatology, 28, 1363-1383. doi:10.1007/s10764-007-9226-5.

Groves, C. P., \& Tattersall, I. (1991). Geographical variation in the fork-marked lemur, Phaner furcifer (Primates, Cheirogaleidae). Folia Primatologica, 56, 39-49. doi:10.1159/000156526.

Grubb, P., Butynski, T. M., Oates, J. F., Bearder, S. K., Disotell, T. R., Groves, C. P., et al. (2003). Assessment of the diversity of African primates. International Journal of Primatology, 24, 13011357. doi:10.1023/B:IJOP.0000005994.86792.b9.

Gunther, A. (1875). Notes on some mammals from Madagascar. Proceedings of the Zoological Society of London, 1875, 78-80.

Hapke, A., Fietz, J., Nash, S. D., Rakotondravony, D., Rakotosamimanana, B., Ramanamanjato, J.-B., et al. (2005). Biogeography of dwarf lemurs (Cheirogaleus spp.): Genetic evidence for unexpected patterns in southeastern Madagascar. International Journal of Primatology, 26, 869-897. doi:10.1007/ s10764-005-5327-0.

Harcourt, C., \& Thornback, J. (1990). Lemurs of Madagascar and the Comoros: The IUCN red data book. Gland, Switzerland and Cambridge, UK: IUCN - The World Conservation Union.

Hawkins, A. F. A., Chapman, P., Ganzhorn, J. U., Bloxam, Q. M., Barlow, S. C., \& Tonge, S. J. (1990). Vertebrate conservation in Ankarana Special Reserve, northern Madagascar. Biological Conservation, 54, 83-110. doi:10.1016/0006-3207(90)90136-D.

Hey, J. (2001). The mind of the species problem. Trends in Ecology \& Evolution, 16, 326-329. doi:10.1016/S0169-5347(01)02145-0.

Hill, W. C. O. (1953). Primates: Comparative anatomy and taxonomy. VIII. Strepsirhini. Edinburgh: Edinburgh University Press.

International Commission on Zoological Nomenclature. (2002). Opinion 1995 (Case 3004): Lorisidae Gray, 1821, Galagidae Gray, 1825 and Indriidae Burnett, 1828 (Mammalia, Primates): Conserved as the correct original spellings. Bulletin of Zoological Nomenclature, 59, 65-67.

Irwin, M. T., Johnson, S. E., \& Wright, P. C. (2005). The state of lemur conservation in south-eastern Madagascar: Population and habitat assessments for diurnal and cathemeral lemurs using surveys, satellite imagery and GIS. Oryx, 39, 204-218. doi:10.1017/S0030605305000451.

IUCN. (2008). 2008 IUCN red list of threatened species. Gland, Switzerland and Cambridge, UK: The International Union for Conservation of Nature (IUCN), Species Survival Commission (SSC) Website: http://www.redlist.org.

Jenkins, P. D. (1987). Catalogue of primates in the British Museum (Natural History) and elsewhere in the British Isles. Part IV: Suborder Strepsirrhii, including the subfossil Madagascan lemurs and Family Tarsiidae. London: British Museum (Natural History).

Johann, A. (1997). Sightings of unusual Hapalemurs. International Zoo News, 44, 222-229.

Johnson, S. E. (2002). Ecology and speciation in brown Lemurs: White-collared Lemur (Eulemur albocollaris) and Hybrids (Eulemur albocollaris $\times$ Eulemur fulvus rufus) in Southeastern Madagascar. Ph.D. Dissertation, The University of Texas, Austin.

Johnson, S. E., \& Wyner, Y. (2000). Notes on the biogeography of Eulemur fulvus albocollaris. Lemur News, 5, 25-28.

Johnson, S. E., Lei, R., Martin, S. K., Irwin, M. T., \& Louis Jr., E. E. (2008). Does Eulemur cinereiceps exist? Preliminary evidence from genetics and ground surveys in southeastern Madagascar. American Journal of Primatology, 70, 372-385. doi:10.1002/ajp.20501.

Jolly, A. (2004). Lords and Lemurs. New York: Houghton Mifflin.

Jolly, A., Albignac, R., \& Petter, J.-J. (1984). The lemurs. In A. Jolly, P. Oberlé, \& R. Albignac (Eds.), Key environments: Madagascar (pp. 183-202). Oxford: Pergamon Press.

Kappeler, P. M., Rasoloarison, R. M., Razafimanantsoa, L., Walter, L., \& Roos, C. (2005). Morphology, behaviour and molecular evolution of giant mouse lemurs (Mirza spp.) Gray, 1970, with description of a new species. Primate Report, 71, 3-26. 
Koenders, L., Rumpler, Y., Ratsirarson, J., \& Peyreiras, A. (1985a). Lemur macaco flavifrons (Gray, 1867): A rediscovered subspecies of primate. Folia Primatologica, 44, 210-215. doi:10.1159/000156214.

Koenders, L., Rumpler, Y., \& Brun, B. (1985b). Notes on the recently rediscovered Sclater's lemur (Lemur macaco flavifrons). Primate Conservation, 6, 35.

Kollman, M. (1910). Note sur les genres Chirogale et Microcebus. Bulletin du Museum D'Histoire Naturelle, Paris, 16, 301-304.

Lahann, P., Schmid, J., \& Ganzhorn, J. U. (2006). Geographical variation in populations of Microcebus murinus in Madagascar: Resource seasonality or Bergmann's rule? International Journal of Primatology, 27, 983-999. doi:10.1007/s10764-006-9055-y.

Lehman, S. M., \& Wright, P. C. (2000). Preliminary study of the conservation status of lemur communities in the Betsakafandrika region of eastern Madagascar. Lemur News, 5, 23-25.

Lei, R., Engberg, S. E., Andriantompohavana, R., McGuire, S. M., Mittermeier, R. A., Zaonarivelo, J. R., et al. (2008). Nocturnal lemur diversity at Masoala National Park. Special Publications of the Museum of Texas Tech University, 53, 1-41.

Louis Jr, E. E., Ratsimbazafy, J. H., Razakamaharauo, V. R., Pierson, D. J., Barber, R. C., \& Brenneman, R. A. (2005). Conservation genetics of black and white ruffed lemurs, Varecia variegata, from southeastern Madagascar. Animal Conservation, 8, 105-111. doi:10.1017/S1367943004001891.

Louis Jr, E. E., Coles, M. S., Andriantompohavana, R., Sommer, J. A., Engberg, S. E., Zaonarivelo, J. R., et al. (2006a). Revision of the mouse lemurs (Microcebus) of eastern Madagascar. International Journal of Primatology, 27, 347-389. doi:10.1007/s10764-006-9036-1.

Louis Jr., E. E., Engberg, S. E., Lei, R., Geng, H., Sommer, J. A., Randriamampionona, R., et al. (2006b). Molecular and morphological analyses of the sportive lemurs (Family Megaladapidae: Genus Lepilemur) reveals 11 previously unrecognized species. Special Publications of the Museum of Texas Tech University, 49, 1-47.

Macedonia, J. M., \& Stanger, K. F. (1994). Phylogeny of the Lemuridae revisited: Evidence from communication signals. Folia Primatologica, 63, 1-43. doi:10.1159/000156787.

Mayor, M., \& Lehman, S. M. (1999). Conservation of Perrier's sifaka (Propithecus diadema perrieri) in Analamera Special Reserve, Madagascar. Lemur News, 4, 21-23.

Mayor, M., Sommer, J. A., Houck, M. L., Zaonarivelo, J. R., Wright, P. C., Ingram, C., et al. (2004). Species status for Malagasy sifakas (Propithecus spp.). International Journal of Primatology, 25, 875-900. doi:10.1023/B:IJOP.0000029127.31190.e9.

Mayr, E. (1963). Animal species and evolution. Cambridge, MA: Harvard University Press.

Mayr, E., \& Ashlock, P. D. (1991). Principles of systematic zoology (2nd ed.). New York: McGraw-Hill.

Meier, B., \& Albignac, R. (1989). Hairy-eared dwarf lemur rediscovered (Allocebus trichotis). Primate Conservation, 10, 30 .

Meier, B., \& Albignac, R. (1991). Rediscovery of Allocebus trichotis Günther 1875 (Primates) in northeast Madagascar. Folia Primatologica, 56, 57-63. doi:10.1159/000156529.

Meier, B., \& Rumpler, Y. (1987). Preliminary survey of Hapalemur simus and of a new species of Hapalemur in eastern Betsileo, Madagascar. Primate Conservation, 8, 40-43.

Meier, B., Albignac, R., Peyrieras, A., Rumpler, Y., \& Wright, P. (1987). A new species of Hapalemur (Primates) from southeast Madagascar. Folia Primatologica, 48, 211-215. doi:10.1159/000156299.

Meyers, D., \& Ratsirarson, J. (1989). Distribution and conservation of two endangered sifakas in northern Madagascar. Primate Conservation, 10, 82-87.

Meyers, D., Rabarivola, C., \& Rumpler, Y. (1989). Distribution and conservation of Sclater's lemur: Implications of a morphological cline. Primate Conservation, 10, 78-82.

Mittermeier, R. A., Tattersall, I., Konstant, W. R., Meyers, D. M., \& Mast, R. B. (1994). Lemurs of Madagascar. Washington, D.C: Conservation International.

Mittermeier, R. A., Konstant, W. R., Hawkins, F., Louis Jr., E. E., Langrand, O., Ratsimbazafy, J., et al. (2006). Lemurs of Madagascar (2nd ed.). Washington, DC: Conservation International.

Montagnon, D., Crovella, S., \& Rumpler, Y. (1993). Comparison of highly repeated DNA sequences in some Lemuridae and taxonomic implications. Cytogenetics and Cell Genetics, 63, 131-134. doi:10.1159/000133518.

Mutschler, T., \& Tan, C. L. (2003). Hapalemur, bamboo or gentle lemurs. In S. M. Goodman, \& J. P. Bensted (Eds.), The natural history of Madagascar (pp. 1324-1329). Chicago: University of Chicago Press.

Nichols, R. (2001). Gene trees and species trees are not the same. Trends in Ecology \& Evolution, 16, 358-363. doi:10.1016/S0169-5347(01)02203-0.

Nicoll, M. E., \& Langrand, O. (1989). Madagascar: Revue de la Conservation et des Aires Protégées. Gland, Switzerland: World Wildlife Fund. 
O'Connor, S. M. (1987). The effect of human impact on vegetation and the consequences to primates in two riverine forests, Southern Madagascar. $\mathrm{PhD}$ dissertation, University of Cambridge, Cambridge, UK.

Olivieri, G., Zimmermann, E., Randrianambinina, B., Rassoloharijaona, S., Rakotondravony, D., Gsuchanski, K., et al. (2007). The ever-increasing diversity in mouse lemurs: Three new species in north and northwestern Madagascar. Molecular Phylogenetics and Evolution, 43, 309-327. doi:10.1016/j.ympev.2006.10.026.

Orr, H. A. (2001). The genetics of species differences. Trends in Ecology \& Evolution, 16, 343-350. doi:10.1016/S0169-5347(01)02167-X.

Pariente, G. (1970). Rétinographies comparées des Lémuriens malgaches. Comptes Rendus des Séances de l'Académie des Sciences, 270, 1404-1407.

Pastorini, J. (2000). Molecular systematics of Lemurs. PhD dissertation, Universität Zürich, Zürich, 183 pp.

Pastorini, J., Forstner, M. R. J., \& Martin, R. D. (2000). Relationships among brown lemurs (Eulemur fulvus) based on mitochondrial DNA sequences. Molecular Phylogenetics and Evolution, 16, 418429. doi:10.1006/mpev.2000.0796.

Pastorini, J., Forstner, M. R. J., \& Martin, R. D. (2001a). Phylogenetic history of sifakas (Propithecus: Lemuriformes) derived from mtDNA sequences. American Journal of Primatology, 53, 1-17. doi:10.1002/1098-2345(200101)53:1<1::AID-AJP1>3.0.CO;2-J.

Pastorini, J., Martin, R. D., Ehresmann, P., Zimmermann, E., \& Forstner, M. R. J. (2001b). Molecular phylogeny of the lemur family Cheirogaleidae (Primates) based on mitochondrial DNA sequences. Molecular Phylogenetics and Evolution, 19, 45-56. doi:10.1006/mpev.2000.0904.

Pastorini, J., Forstner, M. R. J., \& Martin, R. D. (2002). Phylogenetic relationships of gentle lemurs (Hapalemur). Evolutionary Anthropology, 1(Supplement), 150-154. doi:10.1002/evan.10079.

Pastorini, J., Thalmann, U., \& Martin, R. D. (2003). A molecular approach to comparative phylogeography of extant Malagasy lemurs. Proceedings of the National Academy of Sciences of the United States of America, 100, 5879-5884. doi:10.1073/pnas.1031673100.

Patel, E. R., \& Andrianandrasana, L. H. (2008). Low elevation silky sifakas (Propithecus candidus) in the Makira Conservation Site at Andaparaty-Rabeson: Ranging, demography, and possible sympatry with red ruffed lemurs (Varecia rubra). Lemur News, 13, 18-22.

Paterson, H. E. H. (1986). Environment and species. South African Journal of Science, 82, 62-65.

Petter, J.-J. (1962). Recherches sur l'écologie et l'éthologie des lémuriens malgaches. Mémoires de Museum National d'Histoire Naturelle, Paris, 27, 1-146.

Petter, A., \& Petter, J.-J. (1971). Part 3.1 Infraorder Lemuriformes. In J. Meester, \& H. W. Setzer (Eds.), The mammals of Africa: An identification manual (pp. 1-10). Washington, DC: Smithsonian Institution Press.

Petter, J.-J., \& Petter-Rousseaux, A. (1960). Remarques sur la systématique du genre Lepilemur. Mammalia, 24, 76-86.

Petter, J.-J., \& Petter-Rousseaux, A. (1979). Classification of the prosimians. In G. A. Doyle, \& R. D. Martin (Eds.), The study of prosimian behavior (pp. 359-409). London: Academic Press.

Petter, J.-J., Albignac, R., \& Rumpler, Y. (1977). Faune de Madagascar 44: Mammiferes Lémuriens (Primates Prosimiens). Paris: Office de la Recherche Scientifique et Technique d'Outre-Mer (ORSTOM)/Centre National de la Recherche Scientifique (CNRS).

Petter-Rousseaux, A., \& Petter, J.-J. (1967). Contribution a la systématique des Cheirogaleinae (Lémuriens malgaches). Allocebus, gen. nov., pour Cheirogaleus trichotis Gunther 1875. Mammalia, 31, 574582 .

Peters, W. C. H. (1852). Naturwissenschaftliche Reise nach Mossambique. Berlin: Georg Reimer Verlag.

Powzyk, J. A., \& Mowry, C. B. (2003). Dietary and feeding differences between sympatric Propithecus diadema diadema and Indri indri. International Journal of Primatology, 24, 1143-1162. doi:10.1023/ B:IJOP.0000005984.36518.94.

Rabarivola, C., Meyers, D., \& Rumpler, Y. (1991). Distribution and morphological characters of the intermediate forms between the black lemur (Eulemur macaco macaco) and Sclater's lemur (E. $m$. flavifrons). Primates, 32, 269-273. doi:10.1007/BF02381186.

Rabarivola, C., Prosper, P., Zaramody, A., Andriaholinirina, N., \& Hauwy, M. (2007). Cytogenetics and taxonomy of the genus Hapalemur. Lemur News, 12, 46-49.

Rabarivola, C., Zaramody, A., Fausser, J.-L., Andriaholinirina, N., Roos, C., Zinner, D., et al. (2006). Cytogenetic and molecular characteristics of a new species of sportive lemur from northern Madagascar. Lemur News, 11, 45-49. 
Rabeson, P., Randrianarisata, D., Rasabo, P., Andrianoely, D., Razafindrakoto, G., Razafindraibe, D., et al. (2006). Surveys for lemurs and biodiversity in the Baekaora Forest southeast of Kalambatritra Reserve, Madagascar. Lemur News, 11, 5-9.

Radespiel, U., Olivieri, G., Rasolofoson, D. W., Rakotontratsimba, G., Rakotonirainy, O., Rasoloharijanona, S., et al. (2008). Exceptional diversity of mouse lemurs (Microcebus spp.) in the Makira region with the description of one new species. American Journal of Primatology, 70, 1-14.

Rakotoarison, N. (1998). Recent discoveries of the hairy-eared dwarf lemur (Allocebus trichotis). Lemur News, 3, 21.

Rakotoarison, N., Zimmermann, H., \& Zimmermann, E. (1996). First discovery of the hairy-eared dwarf lemur (Allocebus trichotis) in a highland rain forest of eastern Madagascar. Folia Primatologica, 68, 86-94. doi:10.1159/000157235.

Rakotondravony, D., \& Razafindramahatra, L. V. (2004). Contribution à l'étude des populations de Hapalemur aureus dans le couloir forestier Ranomafana-Andringitra. Lemur News, 9, 28-32.

Rakotosamimanana, B., Ralaiarison, R. R., Ralisoamalala, R. C., Rasolofoharivelo, T. M., Raharimanantsoa, V., Randrianarison, R. M., et al. (2004). Comment et pourquoi les lémuriens diurnes disparaissent peu à peu dans les forêts d'Ambato et de Moramanga (région de Moramanga) Madagascar? Lemur News, 9 , $19-24$.

Ralison, F. (2004). Etude histophysiologique des glandes brachiales et antébrachiales chez les lémuriens. Thèse Doctorat Sciences, Majunga, 22 septembre, Madagascar.

Ralison, J. (2006). Rapid assessment of lemurs in southern and southwestern forests of Madagascar. Lemur News, 11, 35-38.

Ramanamanjato, J. B., \& Ganzhorn, J. U. (2001). Effects of forest fragmentation, introduced Rattus rattus and the role of exotic tree plantations and secondary vegetation for the conservation of an endemic rodent and a small lemur in littoral forests of southeastern Madagascar. Animal Conservation, 4, 175183. doi:10.1017/S1367943001001202.

Ranaivoarisoa, J. F., Ramanamahefa, R., Louis Jr, E. E., \& Brenneman, R. A. (2006). Range extension of Perrier's Sifaka, Propithecus perrieri, in the Andrafiamena Classified Forest. Lemur News, 11, 17-21.

Randrianambinina, B., Rasoloharijaona, S., Rakotosamimanana, B., \& Zimmermann, E. (2003). Inventaire des communautés lémuriennes dans la Réserve Spéciale de Bora au nord-ouest et la Forêt dominiale de Mahilaka-Maromandia au nord de Madagascar. Lemur News, 8, 15-18.

Randrianarisoa, P. M., Rasamison, A. A., \& Rakotozafy, L. (1999). Les lémuriens de la region de Daraina: forêt d'Analamazava, forêt de Bekaraoka et forêt de Sahaka. Lemur News, 4, 19-21.

Randriatahina, G. H., \& Rabarivola, J. C. (2004). Inventaire des lémuriens dans la partie nord-ouest de Madagascar et distribution d'Eulemur macaco flavifrons. Lemur News, 9, 7-9.

Rasoazanabary, E. (2004). A preliminary study of mouse lemurs in the Beza Mahafaly Special Reserve, southwest Madagascar. Lemur News, 9, 4-7.

Rasoloarison, R. M., Goodman, S. M., \& Ganzhorn, J. U. (2000). Taxonomic revision of mouse lemurs (Microcebus) in the western portions of Madagascar. International Journal of Primatology, 21, 9631019. doi:10.1023/A:1005511129475.

Rasolofoson, D., Rakotondratsimba, G., Rakotonirainy, O., Rakotozafy, L. M. A., Ratsimbazafy, J. H., Rabetafika, L., et al. (2007). Influence of human pressure on lemur groups on the Makira Plateau, Maroantsetra, Madagascar. Madagascar Conservation and Development, 2, 21-27.

Ravaoarimanana, I. B. (2001). Rapport de la biologie moleculaire de la taxonomie et à l'étude de la spéciation des Lepilemur septentrionalis $\mathrm{PhD}$ Thesis, Université Louis Pasteur, Strasbourg.

Ravaoarimanana, I. B., Montagnon, D., \& Rumpler, Y. (1999). Genetic and cytogenetic studies in speciation of Lepilemur septentrionalis. Lemur News, 4, 33.

Ravaoarimanana, I. B., Tiedemann, R., Montagnon, D., \& Rumpler, Y. (2004). Molecular and cytogenetic evidence for cryptic speciation within a rare endemic Malagasy lemur, the northern sportive lemur (Lepilemur septentrionalis). Molecular Phylogenetics and Evolution, 31, 440-448. doi:10.1016/j. ympev.2003.08.020.

Raxworthy, C. J., \& Rakotondraparany, F. (1988). Mammals report. In N. Quansah (Ed.), Manongarivo special reserve (Madagascar) 1987/88: Expedition report (pp. 122-130). London: Madagascar Environmental Research Group.

Rieseberg, L. H. (2001). Chromosomal rearrangements and speciation. Trends in Ecology \& Evolution, 16, 351-357. doi:10.1016/S0169-5347(01)02187-5.

Rumpler, Y. (1975). The significance of chromosomal studies in the systematics of the Malagasy lemurs. In I. Tattersall, \& R. W. Sussman (Eds.), Lemur biology (pp. 25-40). New York: Plenum Press.

Rumpler, Y. (2000). What cytogenetic studies may tell us about species diversity and speciation in lemurs. International Journal of Primatology, 21, 865-881. doi:10.1023/A:1005598726749. 
Rumpler, Y. (2004). Complementary approaches to cytogeneticsa and molecular biology to the taxonomy and study of speciation processes in lemurs. Evolutionary Anthropology, 13, 67-78. doi:10.1002/ evan.20010.

Rumpler, Y., \& Albignac, R. (1973). Cytogenetic study of the endemic Malagasy lemur: Hapalemur I. Geoffroy, 1851. Journal of Human Evolution, 2, 267-270. doi:10.1016/0047-2484(73)90003-1.

Rumpler, Y., \& Albignac, R. (1975). Intraspecific chromosome variability in a lemur from north of Madagascar: Lepilemur septentrionalis, species nova. American Journal of Physical Anthropology, 42, 425-429. doi:10.1002/ajpa.1330420308.

Rumpler, Y., \& Albignac, R. (1978). Chromosome studies of the Lepilemur, an endemic Malagasy genus of lemurs: Contribution of the cytogenetics to their taxonomy. Journal of Human Evolution, 7, 191196. doi:10.1016/S0047-2484(78)80110-9.

Rumpler, Y., \& Albignac, R. (1979). Cytogenetic study of the Indriidae Bennet, 1832, an endemic Malagasy lemur family. In A. Chiarelli, A. Koen, \& G. Ardito (Eds.), Comparative karyology of primates (pp. 29-34). The Hague: Mouton Publishers.

Rumpler, Y., \& Andriamiandra, A. (1971). Etude histologique des glandes de marquage de la face antérieure du cou de lémuriens malgaches. Comptes Rendus Academie Séances Societe Biologie, 165, 436-441.

Rumpler, Y., \& Dutrillaux, B. (1978). Chromosomal evolution in Malagasy lemurs III Chromosomal banding studiesin the genus Hapalemur and the species Lemur catta. Cytogenetics and Cell Genetics, 21, 201-211. doi:10.1159/000130897.

Rumpler, Y., Ishak, B., Dutrillaux, B., Warter, S., \& Ratsirarison, J. (1986). Chromosomal evolution in Malagasy lemurs: XII. Chromosomal banding studies of Lepilemur mustelinus, L. dorsalis and $L$. edwardsi. Cytogenetics and Cell Genetics, 42, 164-168. doi:10.1159/000132270.

Rumpler, Y., Warter, S., Ishak, B., \& Dutrillaux, B. (1988). Chromosomal evolution in Malagasy lemurs: X. Chromosomal banding studies of Propithecus diadema edwardsi and Indri indri and phylogenic relationships between all the species of the Indriidae. American Journal of Primatology, 16, 63-71. doi:10.1002/ajp.1350160108.

Rumpler, Y., Warter, S., Rabarivola, C., Petter, J.-J., \& Dutrillaux, B. (1990). Chromosomal evolution in Malagasy lemurs: XII. Chromosomal banding study of Avahi laniger occidentalis (Syn: Lichanotus laniger occidentalis) and cytogenetic data in favour of its classification in a species apart-Avahi occidentalis. American Journal of Primatology, 21, 307-316. doi:10.1002/ajp.1350210406.

Rumpler, Y., Warter, S., Hauwy, M., Randrianasolo, V., \& Dutrillaux, B. (1991). Brief report: Cytogenetic study of Hapalemur aureus. American Journal of Physical Anthropology, 86, 81-84. doi:10.1002/ ajpa.1330860107.

Rumpler, Y., Ravoarimanana, I. B., Hauwy, M., \& Warter, S. (2001). Cytogenetic argument in view of taxonomic revision of Lepilemur septentrionalis. Folia Primatologica, 72, 308-315. doi:10.1159/ 000052747.

Rumpler, Y., Prosper, P., Hauwy, M., Rabarivola, C., Rakotoarisoa, G., \& Dutrillaux, B. (2002). Chromosomal evolution of the Hapalemur griseus subspecies (Malagasy Prosimian), including a new chromosomal polymorphic cytotype. Chromosome Research, 10, 145-153. doi:10.1023/ A:1014953202718.

Rumpler, Y., Andriaholinirina, N., Warter, S., Hauwy, M., \& Rabarivola, C. (2004). Phylogenetic history of the sifakas (Propithecus: Lemuriformes) derived from cytogenetic studies. Chromosome Research, $12,453-463$.

Rylands, A. B., \& Mittermeier, R. A. (In press). The diversity of the New World primates: An annotated taxonomy. In P. A. Garber, A. Estrada, J. C. Bicca-Marques, E. W. Heymann, \& K. B. Strier (Eds.), South American primates: Comparative perspectives in the study of behavior, ecology, and conservation. New York: Springer.

Rylands, A. B., Schneider, H., Langguth, A., Mittermeier, R. A., Groves, C. P., \& Rodríguez-Luna, E. (2000). An assessment of the diversity of New World primates. Neotropical Primates, 8, 6193.

Rylands, A. B., Mittermeier, R. A., \& Konstant, W. R. (2002). Species and subspecies of primates described since 1990. Lemur News, 7, 5-6.

Schmid, J. (2000). Conservation planning in the Mantady-Zahamena corridor, Madagascar: Rapid Assessment Program (RAP). Bonner Zoological Monographs, 46, 285-296.

Schmid, J., \& Kappeler, P. M. (1994). Sympatric mouse lemurs (Microcebus spp.) in western Madagascar. Folia Primatologica, 63, 162-170. doi:10.1159/000156812.

Schütz, H., \& Goodman, S. M. (1998). Photographic evidence of Allocebus trichotis in the Reserve Spéciale d'Anjanaharibe-Sud. Lemur News, 3, 21-22. 
Schwab, D., \& Ganzhorn, J. U. (2004). Distribution, population structure and habitat use of Microcebus berthae, compared to those of other cheirogaleids. International Journal of Primatology, 25, 307-330. doi:10.1023/B:IJOP.0000019154.17401.90.

Schwarz, E. (1931). A revision of the genera and species of Madagascar Lemuridae. Proceedings of the Zoological Society of London, 1931, 399-426.

Schwarz, J. H., \& Tattersall, I. (1985). Evolutionary relationships of living lemurs and lorises (Mammalia, Primates) and their potential affinities with European Eocene Adapidae. Anthropological Papers of the American Museum of Natural History, 60, 1-100.

Schwitzer, C., Schwitzer, N., Randriatahina, G. H., \& Kaumanns, W. (2005). Inventory of the Eulemur macaco flavifrons population in the Sahamalaza protected area, northwestern Madagascar, with notes on an unusual color variant of E. macaco. Primate Report Special Issue 72-1:39-40. Abstract. 5 Göttinger Freilandtage 'Primate Diversity_Past, Present and Future', Deutsches Primatenzentrum, Göttingen, December 13-16, 2005.

Schwitzer, C., Schwitzer, N., Randriatahina, G. H., Rabarivola, C., \& Kaumanns, W. (2006). "Programme Sahamalaza": New perspectives for the in situ and ex situ study and conservation of the blue-eyed black lemur (Eulemur macaco flavifrons) in a fragmented habitat. In C. Schwitzer, S. Brandt, O. Ramilijaona, M. Rakotomalala Razanahoera, D. Ackermand, T. Razakamanana, \& J. U. Ganzhorn (Eds.), Proceedings of the German-Malagasy research cooperation in life and earth sciences (pp. 135-149). Berlin: Concept Verlag.

Setchell, J., \& Kappeler, P. M. (2003). Selection in relation to sex in primates. Advances in the Study of Behavior, 33, 87-173. doi:10.1016/S0065-3454(03)33003-7.

Simons, E. L. (1988). A new species of Propithecus (Primates) from northeast Madagascar. Folia Primatologica, 50, 143-151. doi:10.1159/000156340.

Simons, E. L. (1993). Discovery of the western aye-aye. Lemur News, 1, 6.

Simons, E. L., \& Meyers, D. (2001). Folklore and beliefs about the aye aye (Daubentonia madagascariensis). Lemur News, 6, 11-16.

Simons, E. L., \& Rumpler, Y. (1988). Eulemur: A new generic name for species of Lemur other than Lemur catta. Comptes Rendus de l'Académie des Sciences, Paris, Series 3, 307, 547-551.

Simpson, G. G. (1961). Principles of animal taxonomy. New York: Columbia University Press.

Smith, A. (1833). African zoology. South African Quarterly Journal, 2(pt. 1), 17-32.

Stanger-Hall, K. F. (1997). Phylogenetic affinities among the extant Malagasy lemurs based on morphology and behavior. Journal of Mammalian Evolution, 4, 163-194. doi:10.1023/ A:1027345624734.

Stephan, H., \& Bauchot, R. (1965). Hirn-koerpergewichtsbeziehungen bei den halbaffen (Prosimii). Acta Zoologica, 46, 209-231.

Sterling, E. J. (1998). Preliminary report on a survey for Daubentonia madagascariensis and other primate species in the west of Madagascar, June-August 1994. Lemur News, 3, 7-8.

Sterling, E., \& Ramarason, M. (1996). Rapid assessment of the primate fauna of the eastern slope of the Reserve Naturelle Integrale d'Andringitra, Madagascar. Fieldiana Zoology, 85, 293-305.

Sussman, R. W., \& Richard, A. (1986). Lemur conservation in Madagascar: The status of lemurs in the south. Primate Conservation, 7, 85-92.

Sussman, R. W., Green, G. M., Porton, I., Andrianasolondraibe, O. L., \& Ratsirarson, J. (2003). A survey of the habitat of Lemur catta in southwestern and southern Madagascar. Primate Conservation, 19, 32-57.

Tan, C. L. (1999). Group composition, home range, and diet of three sympatric bamboo lemur species (genus Hapalemur) in Ranomafana National Park, Madagascar. International Journal of Primatology, 20, 547-566. doi:10.1023/A:1020390723639.

Tarnaud, L., \& Simmen, B. (2002). A major increase in the population of brown lemurs on Mayotte since the decline reported in 1987. Oryx, 36, 297-300. doi:10.1017/S0030605302000522.

Tattersall, I. (1976a). Notes on the status of Lemur macaco and and Lemur fulvus (Primates, Lemuriformes). Anthropological Papers of the American Museum of Natural History, 53, 257-261.

Tattersall, I. (1976b). Note sur la distribution et sur la situation actuelle des lémuriens des Comores. Mammalia, 40, 519-521.

Tattersall, I. (1977). The lemurs of the Comoro Islands. Oryx, 13, 445-448.

Tattersall, I. (1982). The primates of Madagascar. New York: Columbia University Press.

Tattersall, I. (1985). Systematics of the Malagasy strepsirhine primates. In D. R. Swindler, \& J. Erwin (Eds.), Comparative primate biology, 1: Systematics, evolution and anatomy (pp. 43-72). New York: Alan R. Liss. 
Tattersall, I. (1986). Notes on the distribution and taxonomic status of some species of Propithecus in Madagascar. Folia Primatologica, 46, 51-63. doi:10.1159/000156236.

Tattersall, I. (2007). Madagascar's lemurs: Cryptic diversity or taxonomic inflation? Evolutionary Anthropology, 16, 12-23. doi:10.1002/evan.20126.

Tattersall, I., \& Schwarz, J. H. (1991). Phylogeny and nomenclature in the Lemur-group of Malagasy strepsirhine primates. Anthropological Papers of the American Museum of Natural History, 69, 1-18.

Thalmann, U. (2000a). Greater dwarf lemurs from the Bongolava (central western Madagascar). Lemur News, 5, 33-35.

Thalmann, U. (2000b). Lemur diversity and distribution in western Madagascar-inferences and predictions using a cladistic approach. In W. R. Lourenço, \& S. M. Goodman (Eds.), Diversité et Endemisme à Madagascar (pp. 191-202). Paris: Mémoires de la Société de Biogéographie.

Thalmann, U. (2003). An integrative approach to the study of diversity and regional endemism in lemurs (Primates, Mammalia), and their conservation in western Madagascar. In A. Legakis, S. Sfenthourakis, R. Polymeni, \& M. Thessalou-Legaki (Eds.), The new panorama of animal evolution. Proceedings of the XVIIIth (New) International Congress of Zoology (pp. 409-418). Sofia: Pensoft Publishing.

Thalmann, U., \& Ganzhorn, J. U. (2003). Lepilemur, sportive lemur. In S. M. Goodman, \& J. P. Benstead (Eds.), The natural history of Madagascar (pp. 1336-1340). Chicago: University of Chicago Press.

Thalmann, U., \& Geissmann, T. (2000). Distribution and geographic variation in the western woolly lemur (Avahi occidentalis) with description of a new species (A. unicolor). International Journal of Primatology, 21, 915-941. doi:10.1023/A:1005507028567.

Thalmann, U., \& Geissmann, T. (2005). New species of woolly lemur Avahi (Primates: Lemuriformes) from Bemaraha (Central Western Madagascar). American Journal of Primatology, 67, 371-376. doi:10.1002/ajp.20191.

Thalmann, U., \& Rakotoarison, N. (1994). Distribution of lemurs in central western Madagascar, with a regional distribution hypothesis. Folia Primatologica, 63, 156-161. doi:10.1159/000156811.

Thalmann, U., Geissmann, T., Simona, A., \& Mutschler, T. (1993). The indris of Anjanaharibe-Sud, northeastern Madagascar. International Journal of Primatology, 14, 357-381. doi:10.1007/ BF02192772.

Thalmann, U., Müller, A. E., Kerloc'h, P., \& Zaramody, A. (1999). A visit to the Strict Nature Reserve Tsingy de Namaroka (NW Madagascar). Lemur News, 4, 16-19.

Thalmann, U., Kümmerli, R., \& Zaramody, A. (2002). Why Propithecus verreauxi deckenii and P. $v$. coronatus are valid taxa-quantitative and qualitative arguments. Lemur News, 7, 11-16.

Tomiuk, J., Bachmann, L., Leipoldt, M., Ganzhorn, J. U., Ries, R., Weis, M., et al. (1997). Genetic diversity of Lepilemur mustelinus ruficaudatus, a nocturnal lemur of Madagascar. Conservation Biology, 11, 491-497. doi:10.1046/j.1523-1739.1997.95290.x.

Vargas, A., Jimenez, I., Palomares, F., \& Palacios, M. J. (2002). Distribution, status, and conservation needs of the golden-crowned sifaka (Propithecus tattersalli). Biological Conservation, 108, 325-334. doi:10.1016/S0006-3207(02)00117-9.

Vasey, N., \& Tattersall, I. (2002). Do ruffed lemurs form a hybrid zone? Distribution and discovery of Varecia, with systematic and conservation implications. American Museum Novitates, 3376, 1-26. doi:10.1206/0003-0082(2002)376<0001:DRLFAH>2.0.CO;2.

Vuillaume-Randriamanantena, M., Godfrey, L. R., \& Sutherland, M. R. (1985). Revision of Hapalemur (Prohapalemur) gallieni (Standing, 1905). Folia Primatologica, 45, 89-116. doi:10.1159/000156220.

Warter, S., Randrianasolo, G., Dutrillaux, B., \& Rumpler, Y. (1987). Cytogenetic study of a new subspecies of Hapalemur griseus. Folia Primatologica, 48, 50-55. doi:10.1159/000156284.

Warter, S., Hauwy, M., Dutrillaux, B., \& Rumpler, Y. (2005). Application of molecular cytogenetics for chromsomal evolution of the Lemuriformes (Prosimians). Cytogenetic and Genome Research, 108, 197-203. doi:10.1159/000080816.

Wilme, L., \& Callmander, M. W. (2006). Relic populations of primates: Sifakas. Lemur News, 11, $24-31$.

Wilson, J. M., Stewart, P. D., \& Fowler, S. V. (1988). Ankarana-a rediscovered nature reserve in northern Madagascar. Oryx, 22, 163-171.

Wolf, J. (1822). Der Commerson'sche Maki. Lemur commersonii. Mihi. Abbildungen und Bescchreibungen merkwürdiger maturgeschichlichter Gegenstände, ed. 1, 2, 9-10.

Wright, P. C., Daniels, P. S., Meyers, D. M., Overdorff, D. J., \& Rabesoa, J. (1987). A census and study of Hapalemur and Propithecus in southeastern Madagascar. Primate Conservation, 8, 84-88.

Wright, P. C., Johnson, S. E., Irwin, M. T., Jacobs, R., Schlichting, P., Lehman, S., et al. (2008). The crisis of the critically endangered greater bamboo lemur (Prolemur simus). Primate Conservation, 23, in press. 
Wyner, Y., Absher, R., Amato, G., Sterling, E., Stumpf, R., Rumpler, Y., et al. (1999). Species concepts and the determination of historic gene flow patterns in the Eulemur fulvus (brown lemur) complex. Biological Journal of the Linnean Society. Linnean Society of London, 66, 39-56.

Wyner, Y. M., Johnson, S. E., Stumpf, R. M., \& DeSalle, R. (2002). Genetic assessment of a whitecollared $\times$ red-fronted lemur hybrid zone at Andringitra, Madagascar. American Journal of Primatology, 67, 51-66. doi:10.1002/ajp.10033.

Yoder, A. D. (1997). Back to the future: A synthesis of strepsirhine systematics. Evolutionary Anthropology, 6, 11-22. doi:10.1002/(SICI)1520-6505(1997)6:1<11::AID-EVAN6>3.0.CO;2-Z.

Yoder, A. D., Burns, M. M., \& Genin, F. (2002). Molecular evidence of reproductive isolation in sympatric sibling species of mouse lemurs. International Journal of Primatology, 23, 1335-1343.

Yoder, A. D., Cartmill, M., Ruvolo, M., Smith, K., \& Vigalys, R. (1996). Ancient single origin for Malagasy primates. Proceedings of the National Academy of Sciences of the United States of America, 93, 5122-5126. doi:10.1073/pnas.93.10.5122.

Yoder, A. D., Irwin, J. A., Goodman, S. M., \& Rakotoarisoa, S. V. (1999a). Lemur catta from the Andringitra Massif are Lemur catta. Lemur News, 4, 32-33.

Yoder, A. D., Rakotosimimanana, B., \& Parsons, T. J. (1999b). Ancient DNA in subfossil lemurs: Methodological challenges and their solutions. In H. Rasaminanana, B. Rakotosamimanana, S. M. Goodman, \& J. U. Ganzhorn (Eds.), New directions in Lemur studies (pp. 1-17). New York: Plenum Press.

Yoder, A. D., Rasoloarison, R. M., Goodman, S. M., Irwin, J. A., Atsalis, S., Ravosa, M. J., et al. (2000). Remarkable species diversity in Malagasy mouse lemurs (Primates, Microcebus). Proceedings of the National Academy of Sciences of the United States of America, 97, 11325-11330. doi:10.1073/ pnas.200121897.

Zaonarivelo, J. R., Andriantompohavana, R., Engberg, S. E., Kelley, S. G., Randriamanana, J. C., Louis Jr, E. E., et al. (2007). Morphometric data for Indri (Indri indri) collected from ten forest fragments in eastern Madagascar. Lemur News, 12, 26-29.

Zaramody, A., \& Pastorini, J. (2001). Indications for hybridisation between red-fronted lemurs (Eulemur fulvus rufus) and mongoose lemurs (E. mongoz) in northwest Madagascar. Lemur News, 6, 28-31.

Zaramody, A., Andriaholinirina, N., Rousset, D., \& Rabarivola, C. (2005). Nouvelle répartition respective de Lepilemur microdon et L.mustelinus, et de L. ruficaudatus et L. edwardsi. Lemur News, 10, 19-20.

Zaramody, A., Fausser, J.-L., Roos, C., Zinner, D., Andriaholinirina, N., Rabarivola, C., et al. (2006). Molecular phylogeny and taxonomic revision of the eastern woolly lemurs (Avahi laniger). Primate Report, 74, 9-22.

Zimmermann, E., Ehresmann, P., Zietemann, V., Radespiel, U., Randrianambinina, B., \& Rakotoarison, N. (1997). A new primate species in north-western Madagascar: The golden-brown mouse lemur (Microcebus ravelobensis). Primate Eye, 63, 26-27.

Zimmermann, E., Cepok, S., Rakotoarison, N., Zietemann, V., \& Radespiel, U. (1998). Sympatric mouse lemurs in north-western Madagascar: A new rufous mouse lemur species (Microcebus ravelobensis). Folia Primatologica, 69, 106-114. doi:10.1159/000021571.

Zinner, D., Ostner, J., Dill, A., Razafimanantsoa, L., \& Rasoloarison, R. (2001). Results of a reconnaissance expedition in the western dry forests between Morondava and Morombe. Lemur News, 6, 16-18.

Zinner, D., Roos, C., Fausser, J.-L., Groves, C. P., \& Rumpler, Y. (2007). Disputed taxonomy classification of sportive lemurs (Lepilemiur) in NW Madagascar. Lemur News, 12, 53-56. 